\title{
Weakening and warming of the European Slope Current since the late 1990s attributed to basin-scale density changes.
}

\author{
Matthew Clark ${ }^{1}$, Robert Marsh ${ }^{1}$, James Harle ${ }^{2}$ \\ ${ }^{1}$ Ocean and Earth Science, University of Southampton Waterfront Campus, National Oceanography Centre, European Way, \\ 5 Southampton, SO14 3ZH, UK. \\ ${ }^{2}$ National Oceanography Centre, European Way, Southampton, SO14 3ZH, UK \\ Correspondence to: Matthew Clark (matt.clark@ soton.ac.uk)
}

\begin{abstract}
Oceanic influences on shelf seas are mediated by flow along and across continental slopes, with consequences for regional hydrography and ecosystems. Here we present evidence for the variable North Atlantic influence on European shelf

10 seas over the last four decades, using ocean analysis and reanalysis products, and an eddy-resolving ocean model hindcast. To first order, flows oriented along isobaths at the continental slope are related to the poleward increase of density in the adjacent deep ocean that supports a geostrophic inflow towards the slope. In the North Atlantic, this density gradient and associated inflow has undergone substantial, sometimes abrupt, changes in recent decades. Inflow in the range 10-15 Sv is identified with eastward transport in temperature classes at $30^{\circ} \mathrm{W}$, in the latitude range $45-60^{\circ} \mathrm{N}$. Associated with major 15 subpolar warming around 1997, a cool and fresh branch of the Atlantic inflow was substantially reduced, while a warm and more saline inflow branch strengthened, with respective changes of the order $5 \mathrm{~Sv}$. Total inflow fell from $\sim 15 \mathrm{~Sv}$ pre-1997 to $\sim 10 \mathrm{~Sv}$ post-1997. In the model hindcast, particle tracking is used to trace the origins of poleward flows along the continental slope to the west of Ireland and Scotland, before and after 1997. Backtracking particles up to 4 years, a range of subtropical and subpolar pathways is identified from a statistical perspective. In broad terms, cold, fresh waters of subpolar provenance

20 were replaced by warm, saline waters, of subtropical provenance. These changes have major implications for the downstream shelf regions that are strongly influenced by Atlantic inflow, the northern North Sea in particular, where "subtropicalization" of ecosystems has already been observed since the late 1990s.
\end{abstract}

\section{Introduction}

Over recent decades, the European shelf seas have undergone profound changes in hydrography, biogeochemistry and ecosystems. Major ecosystem changes are most notable in the North Sea. Continuous Plankton Recorder (CPR) data indicate that North Sea ecosystems underwent a regime shift over 1982-88, from a "cold dynamic equilibrium" of 1962-83 to a "warm dynamic equilibrium" of 1984-99 (Beaugrand, 2004). At species level, impacts have been profound: northward shifts in copepod populations (Beaugrand, 2004); steady increase in squid catch since 1980 (van der Kooij et al., 2016); "subtropicalization" of pelagic fish communities (Montero - Serra et al., 2015); evidence that cod recruitment and herring 30 spawning stocks are highly responsive to temperature in the northern North Sea (Akimova et al., 2016). 
https://doi.org/10.5194/os-2021-60

Preprint. Discussion started: 13 July 2021

While these poleward range shifts have been directly attributed to local warming (Beaugrand, 2004), a natural conduit for range expansion is the European Slope Current (henceforth, 'Slope Current'), conveying warm-affinity species from equatorward latitudes to the North Sea. Furthermore, Slope Current water and flow is highly variable. Observations at the Extended Ellett Line repeat hydrographic section off western Scotland indicate background warming and declining nutrient concentrations in upstream flows, from 1996 to the mid-2000s (Johnson et al., 2013). Meanwhile, peak inflows of warm, salty Atlantic Water coincide with Chlorophyll- $a$ increases (McQuatters-Gollop et al., 2007), despite declines in nutrient concentration. CPR data indicate that periodic changes in zooplankton in the North Sea are directly related to variations of Atlantic inflow (Reid et al., 2001;Reid et al., 2003). In conclusion, local warming alone may not explain the rapid,

40 sometimes abrupt, and ongoing changes in community structure and ecosystem functioning in the North Sea. It is likely that the Slope Current provides the connectivity necessary for bottom-up (food supply) and/or top-down (predator) drivers of change.

Variability of the Slope Current related to ecosystem change (Reid et al., 2001;Reid et al., 2003) may be related to basinscale events (Marsh et al., 2017). The North Atlantic is a highly dynamic ocean basin, dominated by two gyre systems: the Subpolar Gyre (SPG) and the Subtropical Gyre (STG). Between the two flows the Gulf Stream, which eventually becomes the North Atlantic Current (NAC), also referred to as the North Atlantic Drift. The NAC brings warmer Atlantic waters from the subtropics across to the eastern boundary and pushes north-eastwards: taking a multi-route path including branches flowing through the Rockall Trough (Holliday et al., 2018). The NAC eventually flows beyond the UK and into the

50 Norwegian Sea. Here, the water cools and sinks, forming the cold, deep return flow which completes the North Atlantic Overturning Circulation (AMOC). However, not all the water follows this pathway. Some of the NAC, which has multiple branches, is entrained into the European Slope Current which flows around the European Shelf (Marsh et al., 2017). Flowing northward along the shelf break and through the Rockall Trough, the current at times is deflected onto the shelf (Porter et al., 2018). However, the majority continues past the tip of Scotland. Some of this water follows the path of the Norwegian

55 Current but some follows the UK coastline, onto the shelf and into the North Sea. Previous estimates suggest that up to $40 \%$ of Slope Current water ends up in the North Sea (Marsh et al., 2017), thus a major input to the European shelf seas.

The Slope Current is a narrow bathymetry-constrained, northward-flowing shelf edge current. It is primarily driven by geostrophic inflow in proportion to the poleward density gradient in the North Atlantic basin (Marsh et al., 2017). It is

60 therefore likely that changes to the density distribution of the North Atlantic could have profound effects on the Slope Current transport and composition, and the wider shelf edge and shelf sea environment. The Slope Current is also partially driven by onshore Ekman flow associated with poleward winds parallel to the coastline and shelf edge (Xu et al., 2015). The current also mixes vertically at the shelf break due to density instabilities or breaking of internal waves, providing an 
https://doi.org/10.5194/os-2021-60

Preprint. Discussion started: 13 July 2021

important mechanism for drawing essential nutrients to the shelf seas (Holt et al., 2009;Huthnance et al., 2009;Mathis et al.,

65 2019). The Slope Current is often characterised in literature as having a high salinity and velocity core at approximately 200 - $300 \mathrm{~m}$ above the $600 \mathrm{~m}$ bathymetry contour (Porter et al., 2018). The subpolar North Atlantic underwent extensive warming in the second half of the 1990s (Marsh et al. 2008), which was sustained well into the 2010s. Superimposed on this warming has been more recent short-term (interannual) variability: temperatures of up to $2{ }^{\circ} \mathrm{C}$ less than the mean were observed in the SPG from 2013, peaking in 2015 (Duchez et al., 2016;Josey et al., 2018). The NAC is influential in conveying material such as pollutants, nutrients and organisms including their larvae into changing shelf sea environments (Huthnance et al., 2009; Reid et al., 2003), which are becoming more or less conducive to any given species, and potentially more conducive to invasive species (Holt et al., 2018;Porter et al., 2018). The SPG and NAC are also known to have significant effects on the geographical shifts of plankton, fish, and whales in the ocean basin and shelf seas. Stronger phases of the SPG have been shown to reduce the amount of plankton and fish observed at the shelf edge and in the Rockall-Hatton

75 Plateau (Hatun et al., 2009). A reduction of the AMOC has previously been suggested in coupled climate-ecosystem models as a mechanism for a suppressed ecosystem in the North Atlantic (Schmittner, 2005). The Atlantic influence on European shelf seas is spatially and temporally variable. The strongest and most variable influence of Atlantic Water is felt along the shelf break and in the northern North Sea (Koul et al., 2019). The Slope Current is a major pathway for bringing waters of sub-polar and sub-tropical origin to the shelf edge and shelf seas. Warmer water arriving from the North Atlantic into the

80 European shelf seas has already been attributed to changes in the ecology and nutrients of UK waters (Holliday and Reid, 2001; Stebbing et al., 2002; Reid et al., 2003; Mathis et al., 2019). Given these changes, it is therefore timely to determine the effects of the changing North Atlantic on Slope Current provenance.

This study has been split into three main aims: to identify the geostrophic inflow to the Slope Current, examine and where possible quantify the effects of changes of this inflow on the Slope Current, and finally to assess and quantify the changing provenance of the Slope Current waters. The rest of the paper is outlined as follows. In Sect. 2, we outline datasets and diagnostics. In Sect. 3, we first examine sub-surface hydrographic variability across the mid-latitudes of the North Atlantic along the eastern shelf break over 1980-2019, followed by analysis of zonal transport variability across mid-latitudes; we then focus on shelf edge transport and establish Lagrangian evidence for the changing provenance of Slope Current water before and after 1997. In Sect. 4, we synthesize these findings in the context of previous studies of large-scale and regional change in the northeast Atlantic and shelf seas.

\section{Methods}

This research used several data sources and resources: two gridded observational data products and an eddy-resolving global ocean model hindcast. Lagrangian computational particle tracking experiments have been conducted to determine the provenance of shelf edge and Slope Current waters. These datasets and diagnostics are outlined in the following sub- 
https://doi.org/10.5194/os-2021-60

Preprint. Discussion started: 13 July 2021

sections. The code used for the data analysis mentioned below and plotting is available separately via Zenodo (Clark et al., 2021).

\subsection{Observational datasets}

For a consistent physical and dynamical description of the North Atlantic, the NOAA gridded dataset known as "GODAS: Global Ocean Data Assimilation System" (NOAA, 2019;Nishida et al., 2011) has been used here. The dataset provides monthly measurements of temperature, salinity, and zonal/meridional components of velocity for $1980-2019$ inclusive. Resolution for all parameters is $1 / 3^{\circ}$ latitude by $1^{\circ}$ longitude, at 40 depth levels. GODAS data is an assimilation of multiple measurement techniques and data sources. We acknowledge that, because of the small scale of the Slope Current, the current itself is not resolved in this dataset. However, it does provide data in sufficient resolution to assess the state and changes in the North Atlantic basin. As an assimilated and gridded dataset, GODAS uses interpolation in space and time to plug gaps in the data, especially at depth. GODAS salinity is mostly "synthetic": it uses a computed salinity profile using the annual T-S relationship of a region (NOAA, 2019;Behringer and Xue, 2004). Despite the fact that GODAS "seriously underestimates salinity variability" (NOAA, 2019), since the density and hence the geostrophic velocity is mainly influenced by temperature variability in the North Atlantic region (based on the analysis presented in the results), it is appropriate for looking at longer term (decadal scale) North Atlantic variability, where density anomalies are predominantly associated with temperature variability . Eastward and northward velocity field is also included in the analysis. For this work, we created a climatology of mean temperature, salinity and density at each chosen depth level, for the entire time series.

The EN4 dataset, sourced from the Met Office Hadley Centre (Good et al., 2013), has also been used, as a dataset

115 independent to GODAS. In-situ temperature and salinity are presented on a $1^{\circ}$ by $1^{\circ}$ grid, with 42 depth levels, a somewhat lower horizontal resolution than GODAS. Similar to GODAS, EN4 provides data collected from 4 different sources (Good et al., 2013), presented as monthly means for the period 1980 - 2019 inclusive.

Monthly climatologies of temperature and salinity were constructed for the entire time series by taking the mean average

120 temperature and salinity per month. Using the calculated climatologies, we have produced anomaly maps (for any selected depth) and meridional profiles, in the form of Hovmöller diagrams, along the shelf edge to capture the greatest density gradient of temperature and salinity. The shelf edge was defined as the first grid cell, reading from east to west, containing data at a grid depth of at least $600 \mathrm{~m}$.

125 Using the Python "Gibbs Sea Water" package, hosting the full Equation of State of Seawater (IOC et al., 2010), density was calculated from the temperature and salinity. The density was then used to calculate the eastward volume transport of water through sections, using the (eastward) Thermal Wind Equation (Equation 1): 
where $\frac{\partial u}{\partial z}=$ eastward velocity change over depth, $g=$ gravitational acceleration, $\rho_{0}=$ reference density, $f=$ Coriolis parameter, $\frac{\partial \rho}{\partial y}=$ change of density over latitude.

Integrating within the upper $1000 \mathrm{~m}$ of water between $45-60^{\circ} \mathrm{N}$ to obtain volume transport $\left(U_{v o l}\right)$ through the section:

$U_{v o l}=\int_{-1000 m}^{0 m} \int_{45^{\circ} N}^{60^{\circ}} \frac{\partial u}{\partial z} d z=\left(\left(\sum(u \times \Delta z)\right) \times \Delta y\right) / 1 e 6$

where $\Delta z$ is the depth step, $\Delta y$ is the change in latitude, and dividing by $1 \times 10^{6}$ provides the transport in Sverdrups (Sv, where $\left.\mathrm{Sv}=1 \times 10^{6} \mathrm{~m}^{3} \mathrm{~s}^{-1}\right)$.

\subsection{Eddy-resolving model output analysis}

140 Observational data has been compared against and complimented with a $1 / 12^{\circ}$ resolution eddy-resolving global ocean model: ORCA12, part of the NEMO family of models (Madec, 2015). In previous studies, the model has been confirmed to be a good representation of North Atlantic subpolar circulation (Marzocchi et al., 2015). Quiver plots of velocity (Figure 1) have been produced for the ORCA12 $250 \mathrm{~m}$ depth level to visually represent the currents at the shelf edge. This provided the evidence showing that shelf-edge flows, including the Slope Current, are resolved in this model. The northward velocity component of the model output has been integrated to produce an estimate of total northward volume transport at the shelf edge. A similar calculation was used to calculate eastward transports in the subpolar North Atlantic. The transport calculation was limited to the upper $1000 \mathrm{~m}$ of the water column. This acts as an indicator for Slope Current transport.

\subsection{Particle trajectory calculations}

150 We use virtual particles to represent water parcels recruited to the Slope Current. To examine the provenance of Slope Current waters, two particle tracking simulations were performed using ARIANE particle modelling software (Blanke and Raynaud, 1997), run backwards (hindcasts) in the qualitative mode. The hindcasts were for the periods $1992-1988$ and 2010 - 2006. The ORCA12 model 5-day means (Madec, 2015) were used to provide the state of the ocean for the simulated years, in a sub-domain of the global ocean with a southern limit at $34.5^{\circ} \mathrm{N}$ and a northern limit ranging - due to the tripolar mesh of ORCA12 - from $64^{\circ} \mathrm{N}$ (around $85^{\circ} \mathrm{W}$ ) to $72.5^{\circ} \mathrm{N}$ (around $30^{\circ} \mathrm{W}$ ). Particles were released proportional to the northwards transport at the shelf edge, between $50-60^{\circ} \mathrm{N}$; as such the exact number of particles released varied with each experiment. Releases were designed to target the "core" of the Slope Current: cells were defined as an active release location 
https://doi.org/10.5194/os-2021-60

Preprint. Discussion started: 13 July 2021

if there was northward transport present and that the bathymetry was between $200-250$ m, taking care to exclude other shallow areas such as the Rockall Bank. The model co-ordinates of the active cells were written to an "initial positions" file to program ARIANE releases. Particles were released monthly (at the start of each month) from the start of the run for each chosen release year and left to run for a maximum of 4 years from the release; many particles reached the domain limit and terminated within 4 years. The calculations provided daily particle location (latitude, longitude, and depth) as well as in-situ temperature, salinity and potential density (relative to the surface). To save computer memory and processing time, we provided the ARIANE software with a set of region limits to restrict the trajectory calculations to the North Atlantic only.

165 The analysis region is a $3 \mathrm{D}$ box; in Cartesian space the box limits are approximately $70{ }^{\circ} \mathrm{W}-15^{\circ} \mathrm{E}, 34-75^{\circ} \mathrm{N}$. This hindcast experiment was run twice: 1992 and 2010, to reflect key events observed in the earlier dataset analysis, in particular the shift to a warmer subpolar North Atlantic.

\section{Results}

In the following section, we first examine sub-surface hydrographic variability in the northern subtropical and subpolar

North Atlantic, and along the eastern shelf break, from the GODAS and EN4 datasets. We then examine the variability of zonal transport across mid-latitudes. Finally, we examine shelf edge meridional transport and present Lagrangian evidence for changing provenance of the Slope Current over the last 40 years.

\subsection{Sub-surface hydrographic variability across mid-latitude North Atlantic and along the eastern shelf break over 1980-2019}

175 Since the Slope Current is defined as being a sub-surface feature, we focus on changes to the mean decadal salinity (Figure 2), temperature (Figure 3), and density (Figure 4) anomalies at the GODAS depth layer of $205 \mathrm{~m}$. Salinity and temperature are closely related throughout the sub-surface North Atlantic Ocean. Where temperature is higher (lower) than the decadal mean, the water is typically more saline (fresher). This pattern is observed in all decades. The trend in temperature anomaly is from a warm subpolar gyre to a cooler subpolar gyre. Density shows an inverse relationship with temperature and the patterns of variability match almost exactly. This is not always true when we compare the salinity to the density anomalies, especially nearer the Labrador Sea, where salinity anomalies are particularly large. Over the study period, there have been notable 'regime shifts' in temperature and density (and to a lesser extent, salinity) of the North Atlantic. The patterns of temperature and density anomalies have changed considerably over time, to the point at which the 2010 s patterns are an approximate inverse of the 1980 s patterns.

185

When examining temperature and salinity as meridional profile time series along-slope, the same strong temperature-density relationship is observed. Hence, depth-averaged ( 0 to the nearest $600 \mathrm{~m}$ depth bin) along-slope density anomaly for GODAS and EN4 (Figure 5) have been plotted. The two datasets show mutual agreement in the magnitude and sign of the anomalies 
https://doi.org/10.5194/os-2021-60

Preprint. Discussion started: 13 July 2021

for the majority of the time series, although some stronger peaks are visible in EN4, especially over $1985-87$ south of $47^{\circ} \mathrm{N}$.

The horizontal bands seen at $48-49^{\circ} \mathrm{N}$ and $55^{\circ} \mathrm{N}$ in Figure $5 \mathrm{a}$ and more widely in $5 \mathrm{~b}$ are an artefact of jumping between grid cells to trace the shelf edge. From 1980 to 1987, the GODAS time series is dominated by a positive density anomaly, less apparent in EN4. A short-lived switch to a negative anomaly is observed at 1990, in both time series, before a more sustained positive density anomaly to 1997 - again clear in both time series. From 1997 onwards, the profiles are dominated by negative anomalies, peaking just after the year 2000 at lower latitudes $\left(<48^{\circ} \mathrm{N}\right)$. This negative density anomaly persists at most of the shelf edge until 2010. From 2010 onwards, anomalies vary between positive and negative values. The density anomalies in Fig. 5, dominated by temperature anomalies, are indicative of variable properties of water circulating in the Slope Current system, in turn related to changing provenance - a theme we return to in Sect. 3.3.

\subsection{Zonal transport variability across North Atlantic mid-latitudes over 1980-2019}

Geostrophic eastward volume transport (Figure 6, GODAS and EN4), calculated via the "thermal wind" equation as detailed in section 2.1, and absolute eastward volume transport (Figure 7, GODAS and ORCA12) has been calculated at $30{ }^{\circ} \mathrm{W}$, between $45-60^{\circ} \mathrm{N}$. Transport was calculated monthly and then annual means taken to remove the large seasonal variability (not shown for GODAS). A "temperature separation" threshold of $11^{\circ} \mathrm{C}$ was determined as appropriate by testing different temperatures in the range $10-12{ }^{\circ} \mathrm{C}$, based on the mean decadal temperature anomalies presented in Figure 3. The GODAS and EN4 geostrophic transport calculations agree strongly, especially in total transport (black lines). Both datasets show a decline in geostrophic zonal transport through the region, with an apparent quickening of the decline from 1997 onwards. The GODAS dataset shows larger, more abrupt changes in transport. For example: the change between 2003 and 2008 is approximately $7 \mathrm{~Sv}$ in the GODAS data, yet only $4 \mathrm{~Sv}$ in EN4. The ORCA12 calculated absolute transport exceeds the GODAS absolute transport by 3 - $5 \mathrm{~Sv}$ throughout the time series. However, the pattern and, in most cases, magnitude of transport variability is a strong match to the absolute and geostrophic transport calculations for EN4 and GODAS. The ORCA12 analysis (Figure 7b) shows the transport declining after a brief peak at 1997, and by 2004 the transport has declined by approximately $10 \mathrm{~Sv}$. This is comparable to the $8-9 \mathrm{~Sv}$ decline of transport during the same period in the GODAS analysis

215 From 1995, the transport begins to switch to a warmer regime $\left(\geq 11^{\circ} \mathrm{C}\right)$. The changes in flow separation are more clearly defined in the geostrophic transport calculations of GODAS than the EN4. By 1999, the cool geostrophic transport decreased to between $0-1 \mathrm{~Sv}$, with some very brief periods of negative (westward) transport of magnitude < $1 \mathrm{~Sv}$. No westward transport is observed in the EN4 time series. In both the geostrophic transport (Figure 6) and the total transport (Figure 7), the cold pathway does begin to grow once again from 2012 in GODAS or 2009 in EN4. However, total transport does not show any sign of increasing to pre-1997 levels. There is a clear continuous dominance of warmer water shown in the 
https://doi.org/10.5194/os-2021-60

Preprint. Discussion started: 13 July 2021

ORCA12 analysis (Figure 7b). The change to a warmer flow regime is more muted but evident to a small degree (on the order of $1-2 \mathrm{~Sv}$ ) since the 1997 peak in transport.

The GODAS geostrophic component (Fig. 6) of transport strongly relates to the peaks shown in the total transport time series (Fig. 7). Total absolute velocity through the same section also shows the same general trends and peaks, but the magnitude of the transports is approximately 5 to $6 \mathrm{~Sv}$ more. The total transport decrease after the 1995 - 97 regime shift is more evident in Figure 7 than the geostrophic transport estimates of Figure 8, with an observed decrease of approximately $10 \mathrm{~Sv}$. The geostrophic transport estimates equate to the baroclinic, temperature and density-driven part of transport, which is slowly changing in relation to the changing density distribution as shown in figures 4 and 5 . The total transport therefore includes the barotropic component.

Figure 8 and 9 show the same GODAS and ORCA12 absolute transports respectively, binned in temperature and salinity space (in intervals of $0.5^{\circ} \mathrm{C}$ and $0.05 \mathrm{PSU}$ ) and shown on a Temperature-Salinity (T-S) diagram for (a) pre-1997 and (b) 1997 onwards, to further understand the observed shift to warmer transport from a water mass perspective. Transport in the

235 GODAS reanalysis is spread across temperatures in the range $5-22{ }^{\circ} \mathrm{C}$ and salinities in the range $34.25-36$ PSU pre-1997 (Fig. 8a). Post-1997 (Fig. 8b) shows a similar temperature distribution but is more constrained in salinity, with a range of 34.7 - 36.2 PSU. The ORCA12 (Fig 9) temperature distribution extends down to $4^{\circ} \mathrm{C}$ but the salinity range, especially pre1997, is more constrained than GODAS. The corresponding potential density ranges are $26.8-27.0 \mathrm{~kg} \mathrm{~m}^{-3}$ (GODAS) and $26.3-27.1 \mathrm{~kg} \mathrm{~m}^{-3}$ (ORCA12), with higher values corresponding to Subpolar Mode Water (McCartney and Talley, 1982). A

240 small amount of negative (westward) transport is observed at temperatures below $7.5{ }^{\circ} \mathrm{C}$ in both analyses. The strongest transports occur at temperatures of $7.5-10{ }^{\circ} \mathrm{C}$ and $35.25-35.50$ PSU in GODAS (Fig. 8) and ORCA12 (Fig. 9): this T-S class transport strengthens by at least $0.02 \mathrm{~Sv}$, but overall transport determined by the sum of the gridcells has decreased. Differences in pre-1997 and post-1997 transport distributions in T-S space are consistent with the declining total transport and increase in the significance of the warmer flow in Figure 6 and Figure 7. An overall regime shift of higher salinities and

245 temperatures is observed in the post-1997 period, with a decrease of total transport. Once again, this is consistent with the time series shown previously. There is a greater spread of temperature from 1997, however a narrower salinity range is apparent.

\subsection{Shelf edge transport and Lagrangian evidence for changing provenance of Slope Current water}

250 To examine how eastward transport in the SPG region of the North Atlantic translates to transport at the shelf edge, two cross-slope transects were identified in the ORCA12 hindcast. The northward transect (at $58.1^{\circ} \mathrm{N}$, Fig. 10a) shows up to 5 times greater annual mean northward transport than the southward section (at $51.1^{\circ} \mathrm{N}$, Fig. 10b), consistent with the 
https://doi.org/10.5194/os-2021-60

Preprint. Discussion started: 13 July 2021

progressive recruitment of transport to the Slope Current (Porter et al., 2018). Northward transport declines at the northward section from 1993 onwards, contemporaneous with the declines in zonal transport evident in Figure 7. Post-1995, the 58.1 ${ }^{\circ} \mathrm{N}$ section shows an almost-steady annual mean northward transport of $2 \mathrm{~Sv}$. The $51.1^{\circ} \mathrm{N}$ section shows much more limited variability.

To trace inflows to the Slope Current, Lagrangian 4-year hindcast experiments were run: releasing virtual water "particles" in 1992 and 2010 at the core of the Slope Current. These dates were chosen to obtain the flow pathway of water towards the shelf edge before and after the 1997 regime shift as observed in the analysis of the observational data (as shown in section 3.2). Figure 13 shows the differences between the two ARIANE particle tracking 4-year hindcast experiments (Figs. 11 and 12): the ensemble mean output for 1992 was subtracted from the 2010 ensemble means. The output, specifically the fractional presence of particles (panel a in figs. 11 - 13) shows a shift - comparing later to earlier backtracking - to a more south-westerly origin of particles ending up at the shelf edge. The vast majority of particles originate off the eastern coast of the United States, with the most followed pathway corresponding with the Gulf Stream and North Atlantic Current. This is also the fastest pathway, with particles off the US east seaboard having a mean age of $\sim 600$ days (Table 1). A smaller fraction of particles can be traced back to the subpolar gyre. The later experiment shows more influence of water traced to the Bay of Biscay. The mean particle depth subplots (panel c in figs. 11 - 13) indicate that most particles originate from depths of approximately 100-150m. Only outside of the NAC and SPG pathway are particles traced to greater depths. The difference plot shows that overall, the 2010 hindcast saw particles become deeper by up to $100 \mathrm{~m}$ (Fig. 13c), particularly the particles of subtropical origin. Flows were slower by approximately 100 days, indicated by the mass red colouring, mainly when following the NAC pathway. There has been a considerable increase in temperature $\left(1^{\circ} \mathrm{C}\right)$ of particles arriving at the shelf edge. This is confirmed in the T-S analysis (Figure 8 and 9) and in the summary statistics presented in Table 1.

275 We can track particles passing a selected meridian: $30^{\circ} \mathrm{W}$ is again been chosen, due to the high prevalence of particles crossing that longitude in both hindcasts. Figures 14 and 15 show histograms of the two hindcasts (1992 and 2010), where particles are tracked passing $30^{\circ} \mathrm{W}$ in the latitude range 40-60 ${ }^{\circ} \mathrm{N}$. Figure 14 shows the latitude (panel a for 1992, c for 2010) and time (particle age, panel $b$ for 1992, $d$ for 2010) at which they crossed. Figure 15 shows the temperature (panel a for 1992, c for 2010) at which they crossed, as well as the depth of crossing (panel b for 1992, d for 2010). Only the first crossing (since release of the hindcast) of $30^{\circ} \mathrm{W}$ is recorded in both figures. The latitude at which the particle first passes 30 ${ }^{\circ} \mathrm{W}$ has shifted south overall, as shown in Fig. 14e. The statistics shown in Table 1 confirm this visual analysis, with the median shifting southward by 1.2 degrees. These observations are consistent with the long-term transport changes, both geostrophic (Figure 6) and absolute (Figure 7). Even more striking is the change of particle age (Fig. 14f). The 2010 hindcast shows a median slowdown of 115 days. This confirms the general pattern evident in the ensemble mean difference plot (Figure 13). The latitude of its first crossing of $30^{\circ} \mathrm{W}$ shows a normal distribution in both hindcasts. However, the spread of 
https://doi.org/10.5194/os-2021-60

Preprint. Discussion started: 13 July 2021

the latitude at which the particles crossed increased by $0.32^{\circ}$, measured by standard deviation (table 1). The spread of particle temperatures (Figure 14e) and particle age (Figure 14f) has also increased in the 2010 hindcast.

\section{Discussion}

290 As determined in a wide range of previous studies, our results have confirmed the North Atlantic is warming and transport is changing over a decadal timescale, despite being highly variable interannually. We first discuss the evidence for physical and dynamical changes in the North Atlantic and associated changes in the Slope Current, followed by consideration of the potential implications of these changes.

\subsection{Variable hydrography and transport}

295 Four decades of observational data have shown that the hydrography of the North Atlantic has changed considerably. Salinity (Fig. 2) and temperature (Fig. 3) variability (and density in Figs 4 and 5, which was calculated as a function of S and T) are clearly linked. However, variation in density anomaly appears to be influenced more by temperature change than of salinity, due to the close inverse relationship between temperature and density anomalies. In the 2010s, positive density anomalies are associated with a cooling in the SPG region; with the core centred at $40{ }^{\circ} \mathrm{W}, 47^{\circ} \mathrm{N}$. This is largely associated with extensive cooling of the SPG from $2013-2015$, which saw anomalies of up to $-2.5{ }^{\circ} \mathrm{C}$ extending to at least $600 \mathrm{~m}$ (Josey et al., 2018). This was then termed the "Big Blue Blob" (or "Cold Blob") by some within the field and indeed the media (Mooney, 2015;Josey et al., 2018).

Associated with basin-scale changes in hydrography are anomalies at the eastern boundary, expressed in density along the continental slope. Plotting density anomalies in time and latitude, there is broad agreement between our analyses of GODAS and EN4 (Figure 5). Meridional coherence of anomalies is consistent with conveyance along the Slope Current pathway, although pulses of positive or negative anomaly appear to originate from the south and weaken poleward in some years. Density anomalies obtained with the EN4 data appear slightly stronger, particularly in lower latitudes. From 1980 - 1988 , there is a strong positive anomaly $\left(>0.18 \mathrm{~kg} \mathrm{~m}^{-3}\right)$ which is present from $45-47{ }^{\circ} \mathrm{N}$ in EN4, which is absent or weaker in GODAS. However, the patterns do become more similar from 1997 onwards. Discrepancies in density are largely attributed to differences in dataset resolution, salinity data collection and gridding methods used in both analysis products (Nishida et al., 2011;Good et al., 2013). EN4 relies on data from ocean profiling instruments, and many of these (such as data from expendable bathythermographs - XBTs) do not contain salinity data (Good et al., 2013). Gaps in the data are filled with a "background" value, which reduces the reliability of the salinity measurement. Temperature anomalies in the two datasets,

315 however, show close agreement (not shown). The early 2000s show a shift from an overall negative temperature anomaly to a positive anomaly (not shown), consistent with the decadal mean anomaly maps in Figure 2. 
Examining large-scale inflow towards the eastern boundary, geostrophic eastward transport estimates obtained with GODAS and EN4, and the corresponding absolute transports in GODAS and ORCA12 (Figs. 6 and 7), show an overall decline in transport of approximately $5 \mathrm{~Sv}$ throughout the time series. EN4 shows large differences in the warm and cold transports. This is likely due to the low resolution and also the gaps in the salinity record, as previously described (Good et al., 2013). There has been an increase in warm-water (southern) inputs to the Slope Current since late 1990's. This has been observed in the transport calculations as well as the ARIANE particle tracking (Fig. 11 - 13 ). The particle tracking calculations provide evidence of a southward shift of water feeding into the Slope Current over the past 3 decades by nearly $1^{\circ}$ of latitude (Fig. 13). This is consistent with the observed southward transport shifts seen in the SPG region (Figs. 6 and 7). Sampled at 5-day time resolution in the ORCA12 hindcast, northward transport at the shelf edge is shown to be highly variable on subseasonal timescales (Fig. 10). Pulses of water near the shelf edge have been observed before: transport anomalies of $+4 \mathrm{~Sv}$ were observed through the Rockall Trough, corresponding to periods of increasing Atlantic input to the North Sea (Holliday and Reid, 2001). Plotting transports in TS space for GODAS (Fig. 8) and ORCA12 (Fig. 9) confirms the shift towards warmer (and more saline) transports. A warming and more saline trend has previously been observed for shelf-edge flows (Berx et al., 2013), although at the time the authors did not determine any trends in volume transport.

\subsection{Implications of the observed changes on the Slope Current and European Shelf Seas}

Changes in the meridional density gradient across mid-latitude North Atlantic drives changes in geostrophic eastward transport that subsequently feeds the shelf edge northward flow (Marsh et al., 2017). Corresponding changes in the strength and properties of the Slope Current are likely to reverberate downstream.

The Slope Current acts to convey water with distinct Atlantic temperature and salinity, as well as nutrients from the North East Atlantic along the shelf edge and eventually into the North Sea (Reid et al., 2003;Porter et al., 2018). Water from the

Slope Current is also upwelled to the surface and transferred to the shelf seas in the Whittard Canyon, south west of Ireland (Porter et al., 2016). The amount of cross-shelf exchange varies seasonally and interannually and can switch to a downwelling mode depending on the strength and direction of Slope Current flow (Porter et al., 2016). This provides an important mechanism for drawing nutrients such as nitrate, phosphate, and silicate from deeper flows onto the shelf (Porter et al., 2016), making them available for biological consumption. Changes in the Slope Current may consequently impact downstream ecosystems through a number of mechanisms. There is growing evidence that recent warming trends have impacted shelf sea species distributions, leading to "subtropicalization" of the North Sea: warmer-water species of zooplankton and fish species have been observed (and in some cases, now breeding) in UK coastal waters (Montero-Serra et al., 2015;Beaugrand et al., 2009;Beare et al., 2004). Not only is the species distribution being altered, the warmer water is 
https://doi.org/10.5194/os-2021-60

Preprint. Discussion started: 13 July 2021

physically affecting fish such as cod with "heat-induced hyperglycaemia" and water oxygen saturation is decreased with the warming water (Beaugrand et al., 2008). With up to $40 \%$ of Slope Current flow destined for the North Sea (Marsh et al., 2017), changes to the provenance and properties of the current could have profound effects to the state of the northern North Sea in particular, and may provide the conduit for the observed "subtropicalization". Whilst the species shift has not been explored in this study, it clearly warrants further work to assess the significance of Slope Current variability on North Sea inputs and ecology.

\section{Conclusions}

We have shown that broad warming of the subpolar North Atlantic Ocean, with a mean of nearly $1{ }^{\circ} \mathrm{C}$ between our two study hindcasts (1992 and 2010), has acted to decrease the meridional density gradient of the region, leading to a general reduction and slowdown in geostrophic transport (by up to $10 \mathrm{~Sv}$ ) feeding the Slope Current. More recent extreme cooling events of up to $2{ }^{\circ} \mathrm{C}$ have also been a major feature, but these have been relatively short lived. Transport towards the shelf edge has been decreasing since 1995-97, although some evidence exists of a slight recovery post-2015. It remains too early to tell if this recovery will persist. Shelf edge northward transport, incorporating the Slope Current, shows a similar pattern but with a smaller magnitude of $2 \mathrm{~Sv}$ north of the Rockall Trough. This relationship supports the theory that a major input to the Slope Current is subpolar gyre water. There has been a gradual, sustained southward shift (of approximately $1^{\circ}$ of latitude) in the water flowing to the shelf edge and being incorporated in the Slope Current. Transport times towards the shelf edge have decreased by an average of 118 days, based on comparison between our two particle back-trajectory ensembles. The spread (standard deviation) of particle latitudes, temperatures, ages and depths at time of crossing $30^{\circ} \mathrm{W}$ have all increased, which is associated with the weakening eastward flow from the subpolar North Atlantic.

370 There are yet unquantified implications of these changes, with particular focus on subtropicalization and nutrient inputs to the North Sea and the rest of the UK/European shelf. Quantifying the effects of the changing Atlantic inputs to the Slope Current and surrounding shelf seas will be examined in further work.

\section{Acknowledgements and funding}

We would like to thank the Natural Environment Research Council for funding this work through the SPITFIRE DTP (grant number: NE/L002531/1). We also thank the National Oceanography Centre for the use of their computer systems and allowing access to the ORCA12 model outputs. Thanks also to Science and Technology Facilities Council (STFC) and the Centre for Environmental Data Analysis (CEDA) for allowing access to the JASMIN computer systems. 
https://doi.org/10.5194/os-2021-60

Preprint. Discussion started: 13 July 2021

(c) Author(s) 2021. CC BY 4.0 License.

\section{Competing interests}

The authors declare that they have no conflict of interest.

\section{Code and Data Availability}

GODAS data provided by the NOAA/OAR/ESRL PSD, Boulder, Colorado, USA, freely available from their website at https://www.esrl.noaa.gov/psd/. EN4 data provided by the Met Office Hadley Centre, UK, freely available from their website at https://www.metoffice.gov.uk/hadobs/en4/index.html. ARIANE Lagrangian particle tracking software was freely provided by B. Blanke and N. Grima, Laboratoire de Physique des Océans, France. ORCA12 data is provided on request to the National Oceanography Centre, UK. Code used for data analysis and plotting in this project is available via the public repository service "Zenodo" (Clark et al., 2021), doi: 10.5281/zenodo.4965881. Data analysis and plotting of Figs. 1 - 10 was performed using Python 2.7 in a Spyder environment (environment file is provided in the Zenodo repository). Figs. 11 15 use Matlab script coded in Matlab 2017a. 


\section{References}

Akimova, A., Núñez-Riboni, I., Kempf, A., and Taylor, M. H.: Spatially-Resolved Influence of Temperature and Salinity on Stock and Recruitment Variability of Commercially Important Fishes in the North Sea, PLOS ONE, 11, e0161917, 10.1371/journal.pone.0161917, 2016.

395 Beare, D. J., Burns, F., Greig, A., Jones, E. G., Peach, K., Kienzle, M., McKenzie, E., and Reid, D. G.: Long-term increases in prevalence of North Sea fishes having southern biogeographic affinities, Marine Ecology Progress Series, 284, 269-278, DOI 10.3354/meps284269, 2004.

Beaugrand, G.: The North Sea regime shift: evidence, causes, mechanisms and consequences, Prog Oceanogr, 60, 245-262, 10.1016/j.pocean.2004.02.018, 2004.

400 Beaugrand, G., Edwards, M., Brander, K., Luczak, C., and Ibanez, F.: Causes and projections of abrupt climate-driven ecosystem shifts in the North Atlantic, Ecology Letters, 11, 1157-1168, 10.1111/j.1461-0248.2008.01218.x, 2008.

Beaugrand, G., Luczak, C., and Edwards, M.: Rapid biogeographical plankton shifts in the North Atlantic Ocean, Global Change Biol, 15, 1790-1803, 10.1111/j.1365-2486.2009.01848.x, 2009.

Behringer, D., and Xue, Y.: Evaluation of the global ocean data assimilation system at NCEP: The Pacific Ocean, Eighth

405 Symposium on Integrated Observing and Assimilation Systems for Atmosphere, Oceans and Land Surface, AMS 84th Annual Meeting, Washington State Convention and Trade Center, Seattle, Washington, 2004,

Berx, B., Hansen, B., Osterhus, S., Larsen, K. M., Sherwin, T., and Jochumsen, K.: Combining in situ measurements and altimetry to estimate volume, heat and salt transport variability through the Faroe-Shetland Channel, Ocean Science, 9, 639654, 10.5194/os-9-639-2013, 2013.

410 Blanke, B., and Raynaud, S.: Kinematics of the Pacific Equatorial Undercurrent: An Eulerian and Lagrangian approach from GCM results, Journal of Physical Oceanography, 27, 1038-1053, Doi 10.1175/1520-0485(1997)027<1038:Kotpeu>2.0.Co;2, 1997.

Clark, M., Marsh, R., and Harle, J.: Code for "Weakening and warming of the European Slope Current since the late 1990s attributed to basin-scale density changes". Zenodo, 10.5281/zenodo.4965881 , 2021.

415 Duchez, A., Frajka-Williams, E., Josey, S. A., Evans, D. G., Grist, J. P., Marsh, R., McCarthy, G. D., Sinha, B., Berry, D. I., and Hirschi, J. J.-M.: Drivers of exceptionally cold North Atlantic Ocean temperatures and their link to the 2015 European heat wave, Environmental Research Letters, 11, 1-19, 10.1088/1748-9326/11/7/074004, 2016.

Good, S. A., Martin, M. J., and Rayner, N. A.: EN4: Quality controlled ocean temperature and salinity profiles and monthly objective analyses with uncertainty estimates, J Geophys Res-Oceans, 118, 6704-6716, 10.1002/2013jc009067, 2013.

420 Hatun, H., Payne, M. R., Beaugrand, G., Reid, P. C., Sando, A. B., Drange, H., Hansen, B., Jacobsen, J. A., and Bloch, D.: Large bio-geographical shifts in the north-eastern Atlantic Ocean: From the subpolar gyre, via plankton, to blue whiting and pilot whales, Prog Oceanogr, 80, 149-162, 10.1016/j.pocean.2009.03.001, 2009. 
https://doi.org/10.5194/os-2021-60

Preprint. Discussion started: 13 July 2021

Holliday, N. P., and Reid, P. C.: Is there a connection between high transport of water through the Rockall Trough and ecological changes in the North Sea?, Ices J Mar Sci, 58, 270-274, 10.1006/jmsc.2000.01008, 2001.

Holliday, N. P., Bacon, S., Cunningham, S. A., Gary, S. F., Karstensen, J., King, B. A., Li, F., and Mcdonagh, E. L.: Subpolar North Atlantic Overturning and Gyre-Scale Circulation in the Summers of 2014 and 2016, J Geophys Res-Oceans, 123, 4538-4559, 10.1029/2018jc013841, 2018.

Holt, J., Wakelin, S., and Huthnance, J.: Down-welling circulation of the northwest European continental shelf: A driving mechanism for the continental shelf carbon pump, Geophysical Research Letters, 36, 10.1029/2009GL038997, 2009.

Holt, J., Polton, J., Huthnance, J., Wakelin, S., O'Dea, E., Harle, J., Yool, A., Artioli, Y., Blackford, J., Siddorn, J., and Inall, M.: Climate-Driven Change in the North Atlantic and Arctic Oceans Can Greatly Reduce the Circulation of the North Sea, Geophysical Research Letters, 45, 11827-11836, 10.1029/2018g1078878, 2018.

Huthnance, J. M., Holt, J. T., and Wakelin, S. L.: Deep ocean exchange with west-European shelf seas, Ocean Sci., 5, 621634, 10.5194/os-5-621-2009, 2009.

435 IOC, SCOR, and IAPSO: The international thermodynamic equation of seawater - 2010: Calculation and use of thermodynamic properties, Intergovernmental Oceanographic Commission, Manuals and Guides no. 56, UNESCO, 196 pp., 2010.

Johnson, C., Inall, M., and Hakkinen, S.: Declining nutrient concentrations in the northeast Atlantic as a result of a weakening Subpolar Gyre, Deep-Sea Res I, 82, 95-107, 10.1016/j.dsr.2013.08.007, 2013.

440 Josey, S. A., Hirschi, J. J. M., Sinha, B., Duchez, A., Grist, J. P., and Marsh, R.: The Recent Atlantic Cold Anomaly: Causes, Consequences, and Related Phenomena, Annu Rev Mar Sci, 10, 475-501, 10.1146/annurev-marine-121916-063102, 2018.

Koul, V., Schrum, C., Düsterhus, A., and Baehr, J.: Atlantic Inflow to the North Sea Modulated by the Subpolar Gyre in a Historical Simulation With MPI-ESM, Journal of Geophysical Research: Oceans, 124, 1-20, 10.1029/2018JC014738, 2019.

Madec, G.: NEMO ocean engine, Note du Pole de modélisation, Institut Pierre-Simon Laplace (IPSL), France., 2015.

445 Marsh, R., Haigh, I. D., Cunningham, S. A., Inall, M. E., Porter, M., and Moat, B. I.: Large-scale forcing of the European Slope Current and associated inflows to the North Sea, Ocean Science, 13, 315-335, 10.5194/os-13-315-2017, 2017.

Marzocchi, A., Hirschi, J. J.-M., Holliday, N. P., Cunningham, S. A., Blaker, A. T., and Coward, A. C.: The North Atlantic subpolar circulation in an eddy-resolving global ocean model, J Marine Syst, 142, 126-143, 10.1016/j.jmarsys.2014.10.007, 2015.

450 Mathis, M., Elizalde, A., and Mikolajewicz, U.: The future regime of Atlantic nutrient supply to the Northwest European Shelf, J Marine Syst, 189, 98-115, 10.1016/j.jmarsys.2018.10.002, 2019.

McCartney, M. S., and Talley, L. D.: The Subpolar Mode Water of the North Atlantic Ocean, Journal of Physical Oceanography, 12, 1169-1188, 10.1175/1520-0485(1982)012<1169:Tsmwot>2.0.Co;2, 1982. 
https://doi.org/10.5194/os-2021-60

Preprint. Discussion started: 13 July 2021

McQuatters-Gollop, A., Raitsos, D. E., Edwards, M., Pradhan, Y., Mee, L. D., Lavender, S. J., and Attrill, M. J.: A long-term chlorophyll dataset reveals regime shift in North Sea phytoplankton biomass unconnected to nutrient levels, Limnology and Oceanography, 52, 635-648, 10.4319/lo.2007.52.2.0635, 2007.

Montero-Serra, I., Edwards, M., and Genner, M. J.: Warming shelf seas drive the subtropicalization of European pelagic fish communities, Global Change Biol, 21, 144-153, 10.1111/gcb.12747, 2015.

Why some scientists are worried about a surprisingly cold 'blob' in the North Atlantic Ocean: https://www.washingtonpost.com/news/energy-environment/wp/2015/09/24/why-some-scientists-are-worried-about-a-coldblob-in-the-north-atlantic-ocean/, access: April 2017, 2015.

Nishida, T., Kitakado, T., Matsuura, H., and Wang, S.-P.: Validation of the Global Ocean Data Assimilation System (GODAS) data in the NOAA National Centre for Environmental System (NCEP) by theory, comparative studies, applications and sea truth, IOTC 9th WPB meeting, IOTC-2011-WPTT13-INF05, 1-18, 2011.

NOAA, E. S. R. L.: NCEP Global Ocean Data Assimilation System (GODAS) at NOAA ESRL/PSD. 2019.

Porter, M., Inall, M. E., Hopkins, J., Palmer, M. R., Dale, A. C., Aleynik, D., Barth, J. A., Mahaffey, C., and Smeed, D. A.: Glider observations of enhanced deep water upwelling at a shelf break canyon: A mechanism for cross-slope carbon and nutrient exchange, Journal of Geophysical Research: Oceans, 121, 7575-7588, 10.1002/2016JC012087, 2016.

Porter, M., Dale, A. C., Jones, S., Siemering, B., and Inall, M. E.: Cross-slope flow in the Atlantic Inflow Current driven by the on-shelf deflection of a slope current, Deep-Sea Res Pt I, 140, 173-185, 10.1016/j.dsr.2018.09.002, 2018.

Reid, P. C., Holliday, N. P., and Smyth, T. J.: Pulses in the eastern margin current and warmer water off the north west European shelf linked to North Sea ecosystem changes, Marine Ecology Progress Series, 215, 283-287, doi:10.3354/meps215283, 2001.

Reid, P. C., Edwards, M., Beaugrand, G., Skogen, M., and Stevens, D.: Periodic changes in the zooplankton of the North Sea during the twentieth century linked to oceanic inflow, Fish. Oceanogr., 12, 260-269, 10.1046/j.1365-2419.2003.00252.x, 2003.

Schmittner, A.: Decline of the marine ecosystem caused by a reduction in the Atlantic overturning circulation, Nature, 434, 628-633, 10.1038/nature03476, 2005.

Stebbing, A. R. D., Turk, S. M. D., Wheeler, A., and Clarke, K. R.: Immigration of southern fish species to south-west 480 England linked to warming of the North Atlantic (1960-2001), J. Mar. Bio. Assoc. U.K., 82, 177-180, 10.1017/S0025315402005325, 2002.

van der Kooij, J., Engelhard, G. H., and Righton, D. A.: Climate change and squid range expansion in the North Sea, Journal of Biogeography, 43, 2285-2298, 10.1111/jbi.12847, 2016.

Xu, W. D., Miller, P. I., Quartly, G. D., and Pingree, R. D.: Seasonality and interannual variability of the European Slope 485 Current from 20 years of altimeter data compared with in situ measurements, Remote Sensing of Environment, 162, 196207, 10.1016/j.rse.2015.02.008, 2015. 
(a) Velocity quiver at $245 \mathrm{~m}$

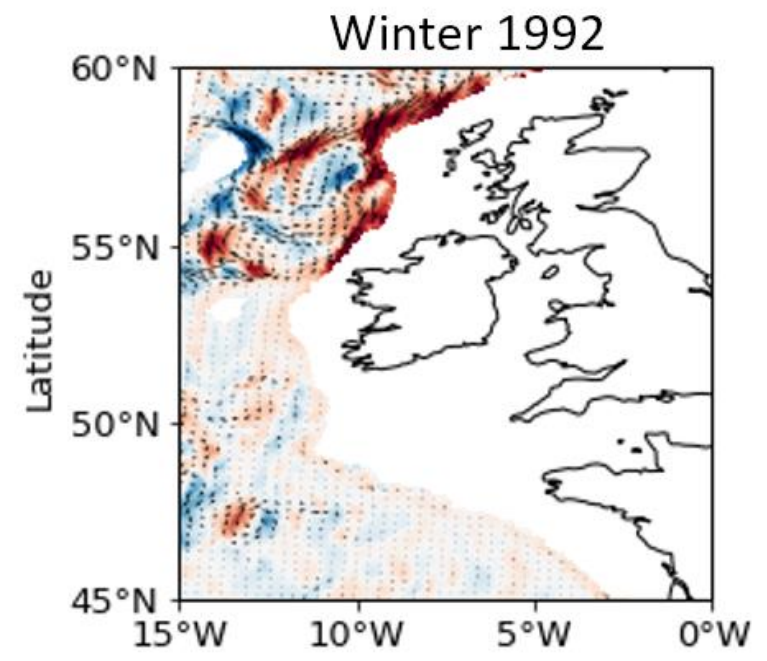

(c) Velocity quiver at $245 \mathrm{~m}$

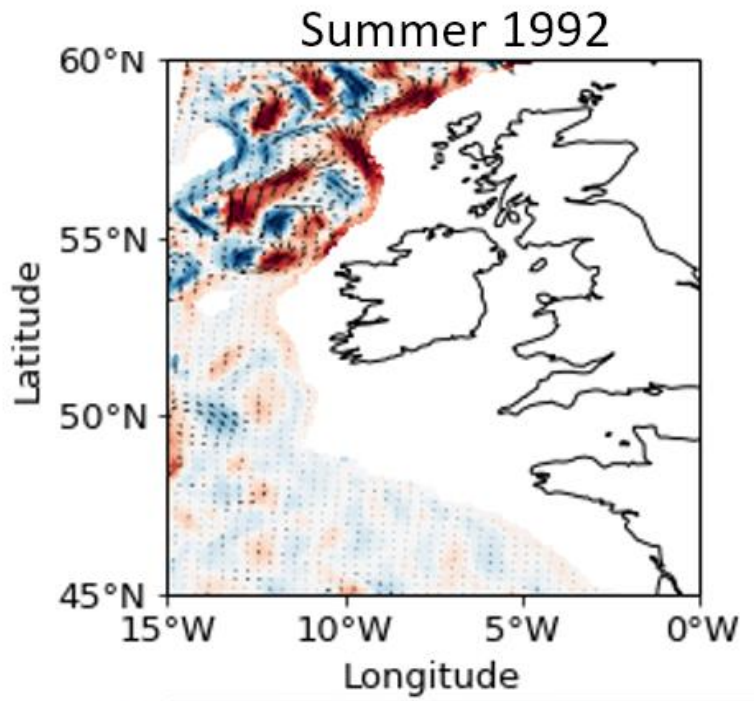

(b) Velocity quiver at $245 \mathrm{~m}$

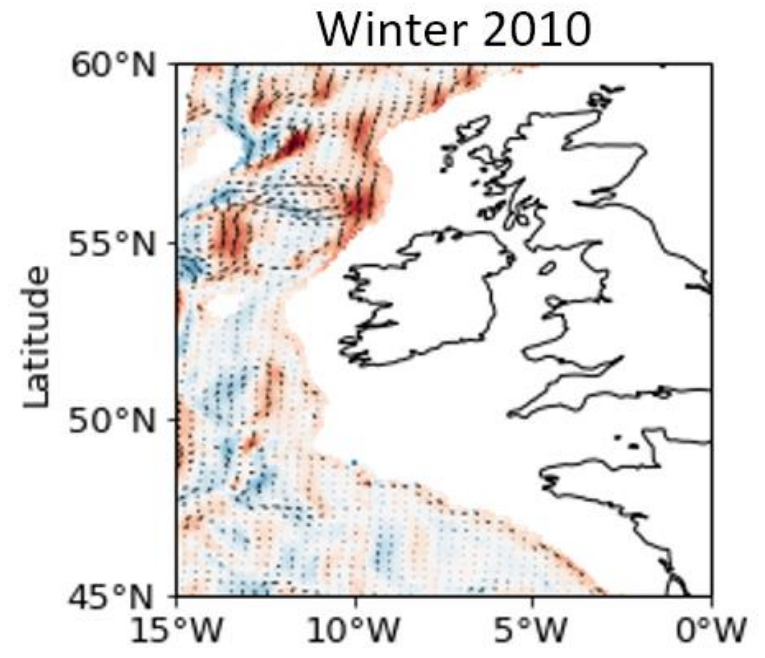

(d) Velocity quiver at $245 \mathrm{~m}$

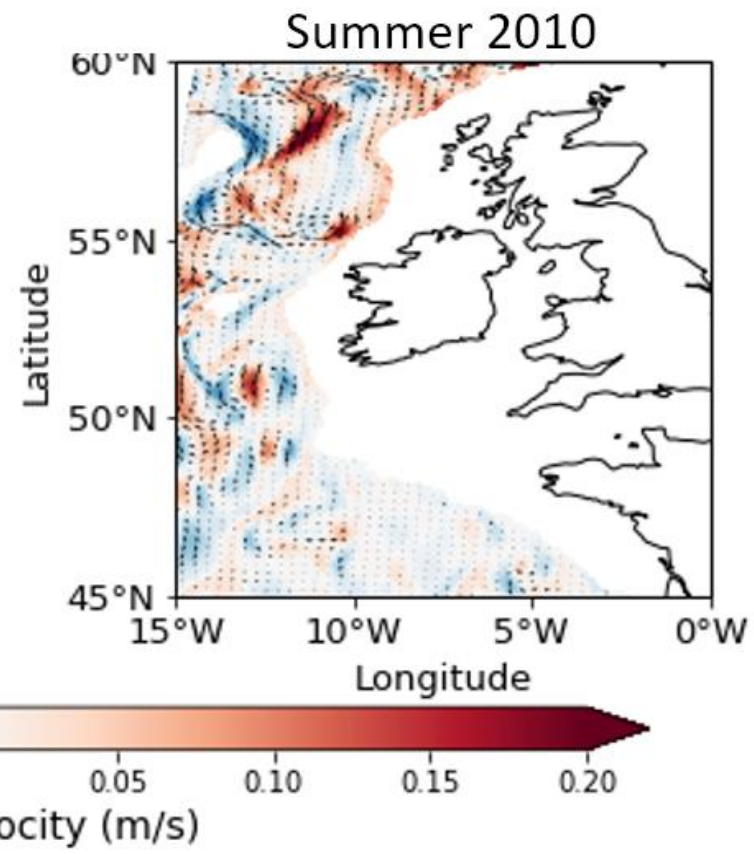

Figure 1: quiver plot, using ORCA12 data, indicating subsurface ( $245 \mathrm{~m})$ relative velocity magnitude and direction of the water, comparing winter and summer releases: (a) winter 1992; (b) winter 2010; (c) summer 1992; (d) summer 2010. Background colour highlights the magnitude of the $v$ component of velocity, positive northwards. 
(a) S decadal mean anomaly, 1980s, 205m

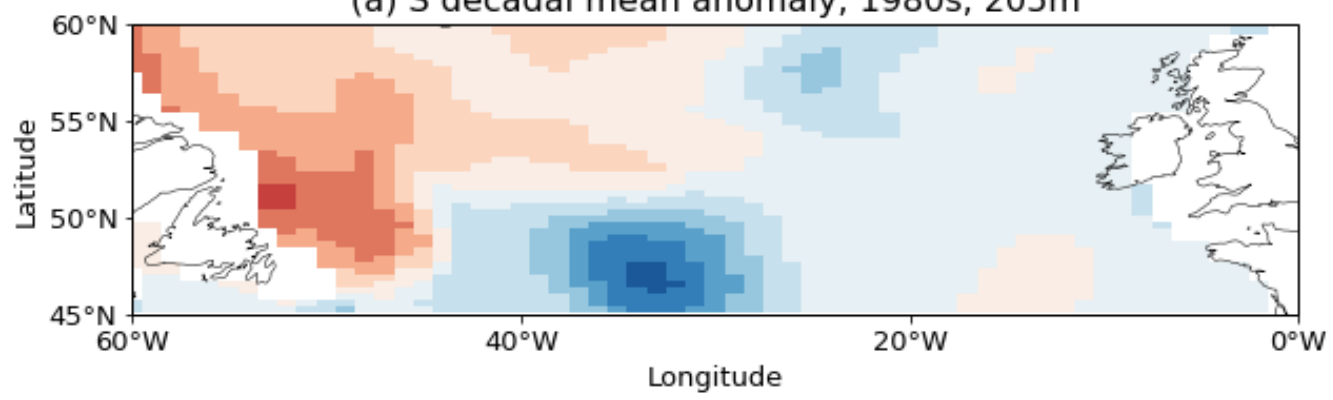

(b) S decadal mean anomaly, 1990s, 205m

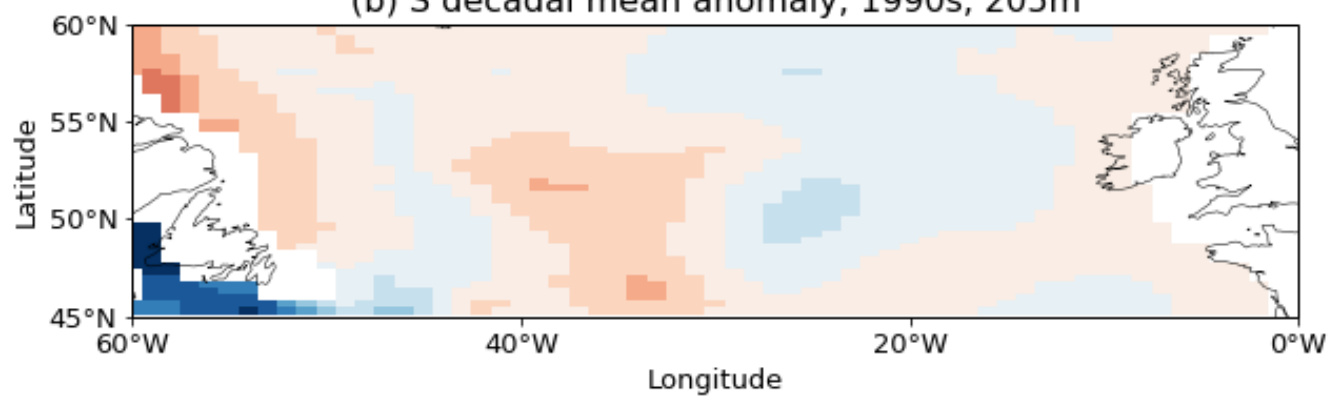

(c) S decadal mean anomaly, 2000s, $205 \mathrm{~m}$
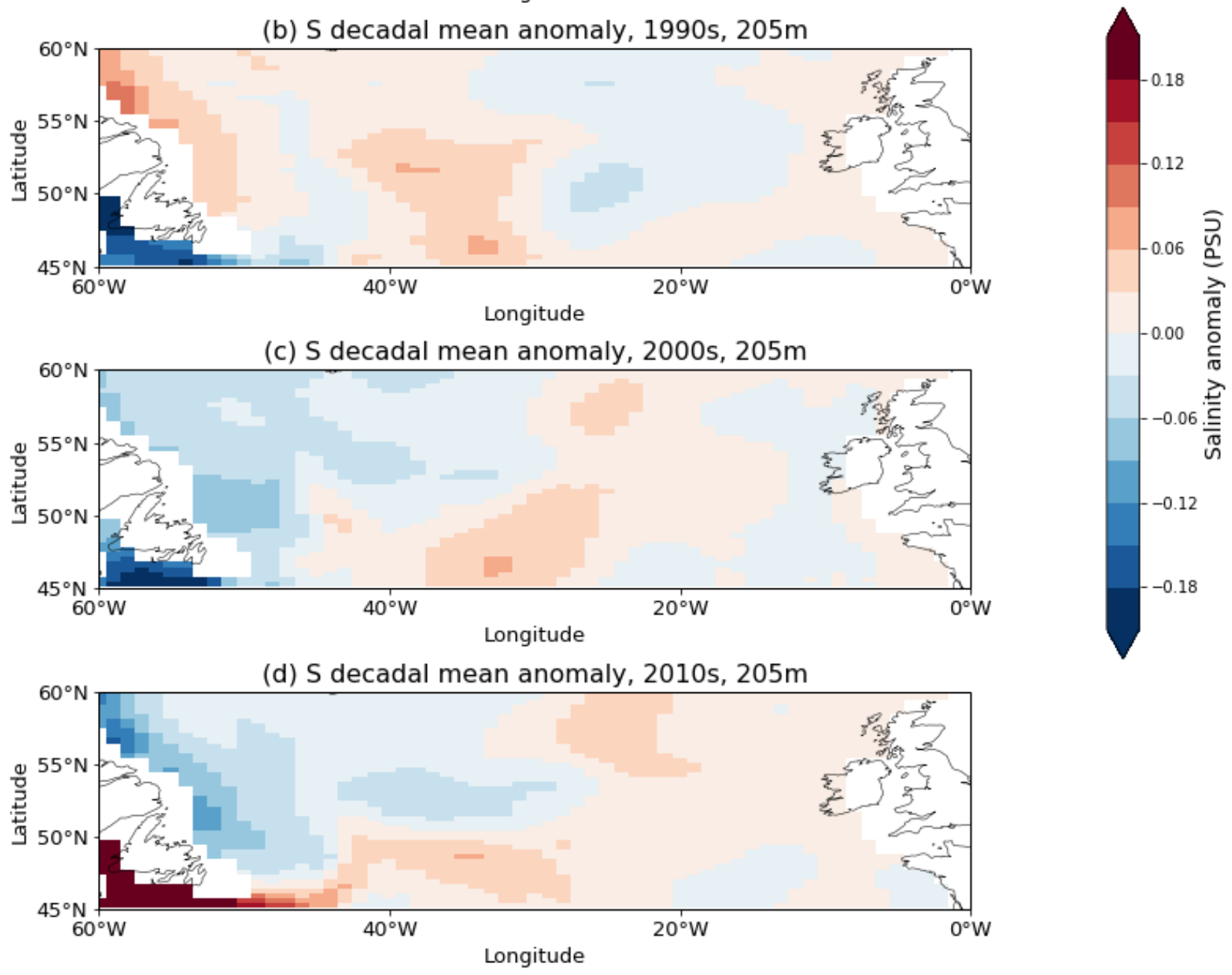

Figure 2: Decadal mean anomaly maps of salinity at $205 \mathrm{~m}$ below the surface: (a) 1980s; (b) 1990s; (c) 2000s, (d) 2010s. Data from GODAS. Anomalies calculated with respect to the 1980 - 2019 climatology. 
https://doi.org/10.5194/os-2021-60

Preprint. Discussion started: 13 July 2021

(c) Author(s) 2021. CC BY 4.0 License.

(a) T decadal mean anomaly, 1980s, 205m

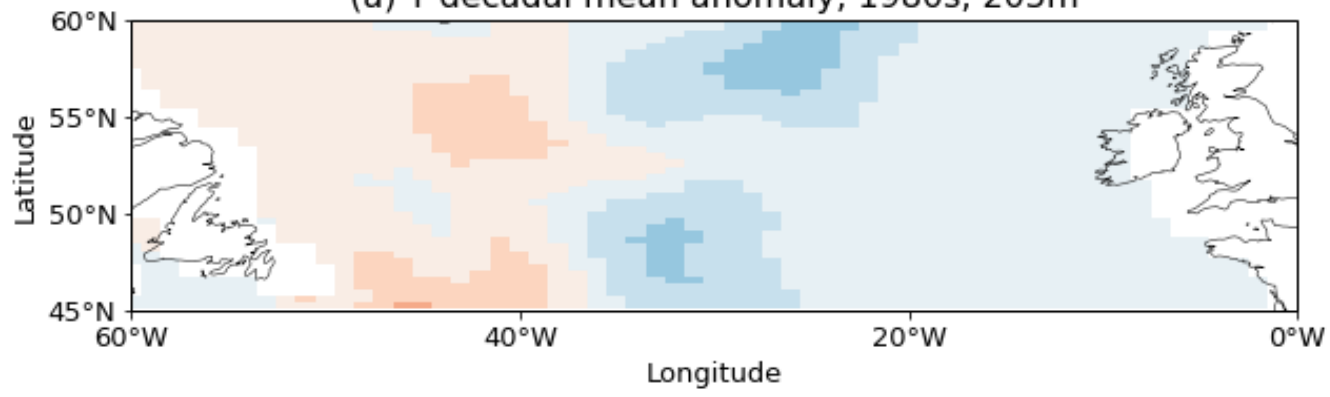

(b) T decadal mean anomaly, 1990s, 205m

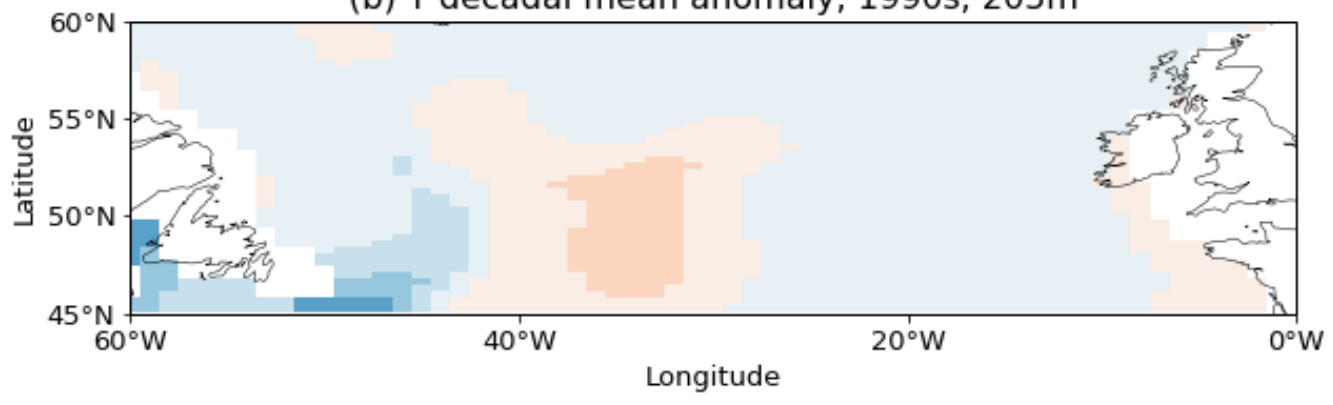

(c) T decadal mean anomaly, 2000s, $205 \mathrm{~m}$
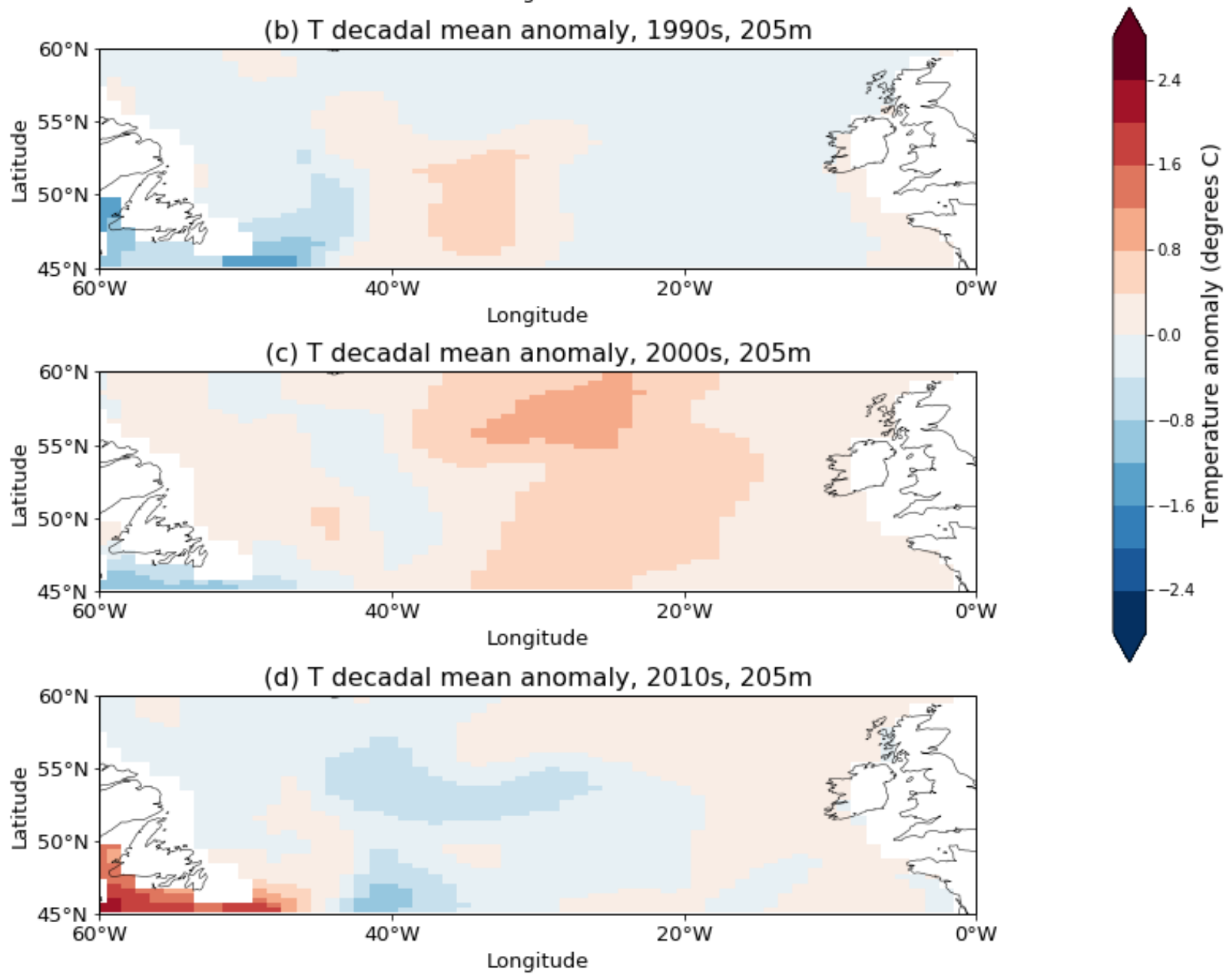

Figure 3: Decadal mean anomaly maps of temperature at $205 \mathrm{~m}$ below the surface: (a) 1980s; (b) 1990s; (c) 2000s, (d) 2010s. Data from GODAS. Anomalies calculated with respect to the 1980 - 2020 climatology. 
(a) Density decadal mean anomaly, 1980s, $205 \mathrm{~m}$

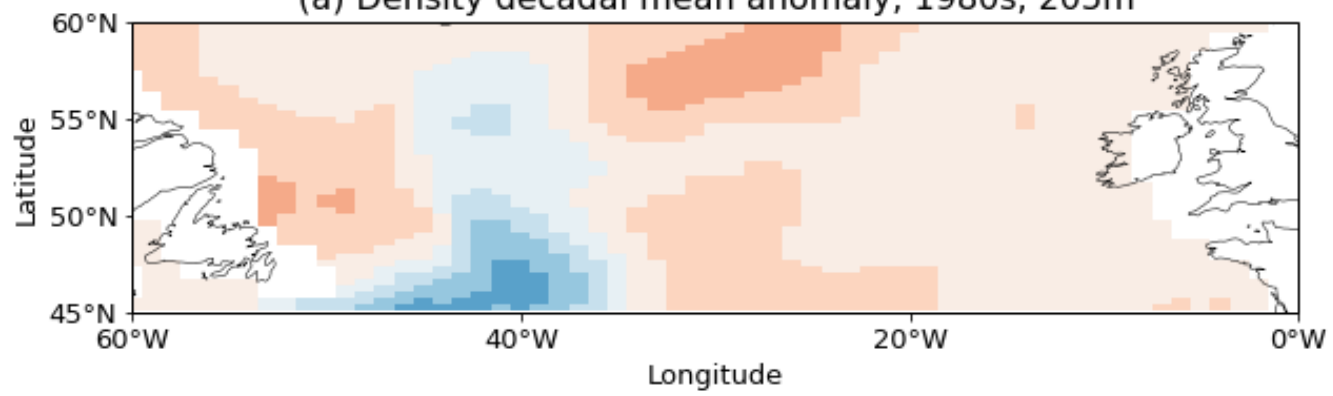

(b) Density decadal mean anomaly, 1990s, 205m

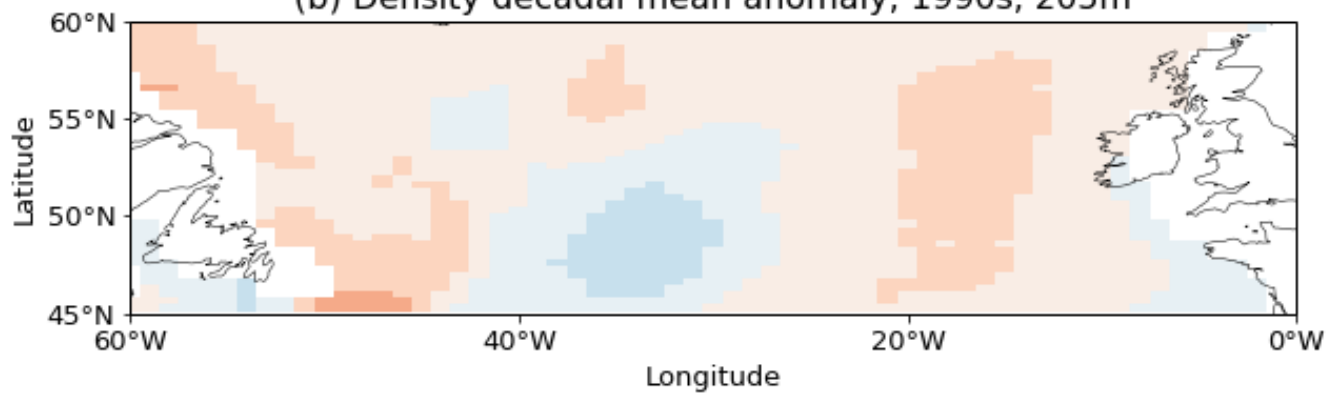

(c) Density decadal mean anomaly, 2000s, $205 \mathrm{~m}$
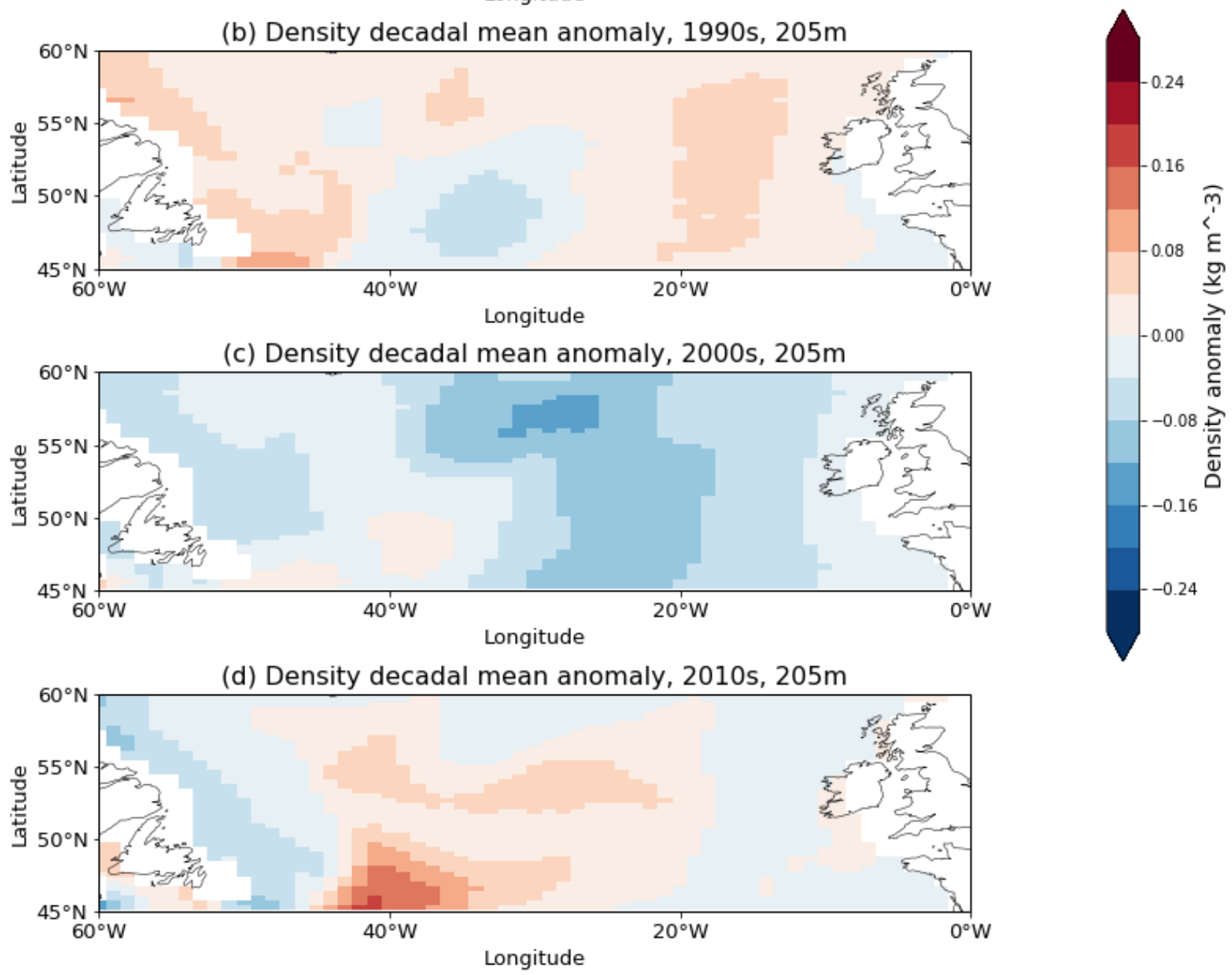

Figure 4: Decadal mean anomaly maps of density at $205 \mathrm{~m}$ below the surface: (a) 1980s; (b) 1990s; (c) 2000s, (d) 2010s. Data from GODAS. Anomalies calculated with respect to the 1980 - 2020 climatology. 


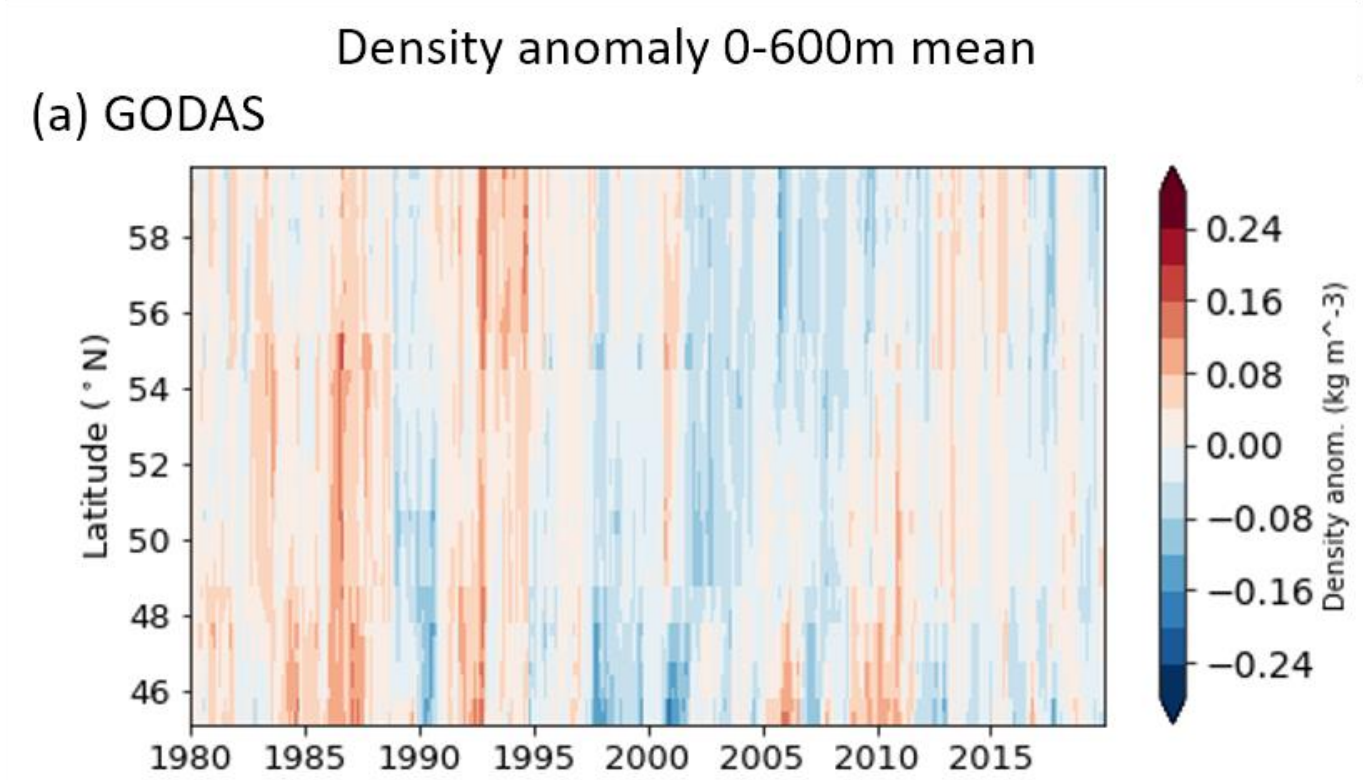

(b) EN4

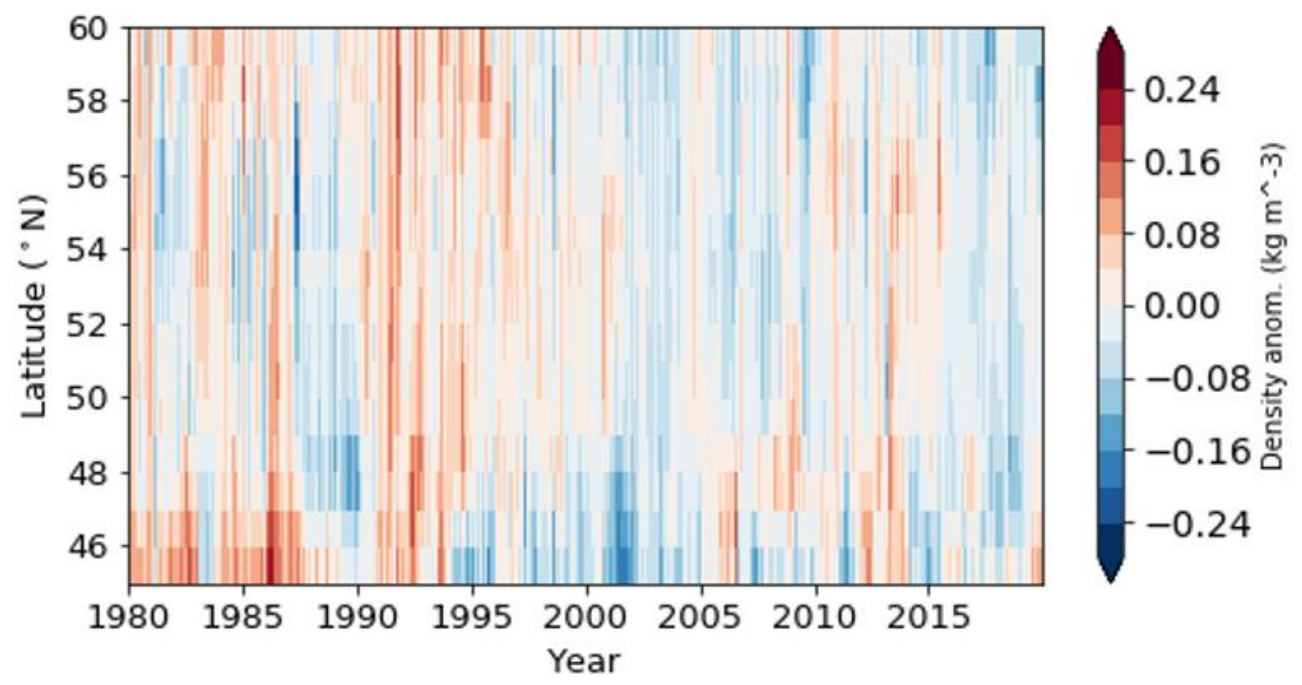

Figure 5: Time series Hovmöller plot of (a) GODAS and (b) EN4 mean density anomaly, averaged over depth levels 0 - 600 m, at the shelf edge between $45-60{ }^{\circ} \mathrm{N}$. 
(a) GODAS Geostrophic eastward transport at 30W, $45.2-60.2 \mathrm{~N}$.

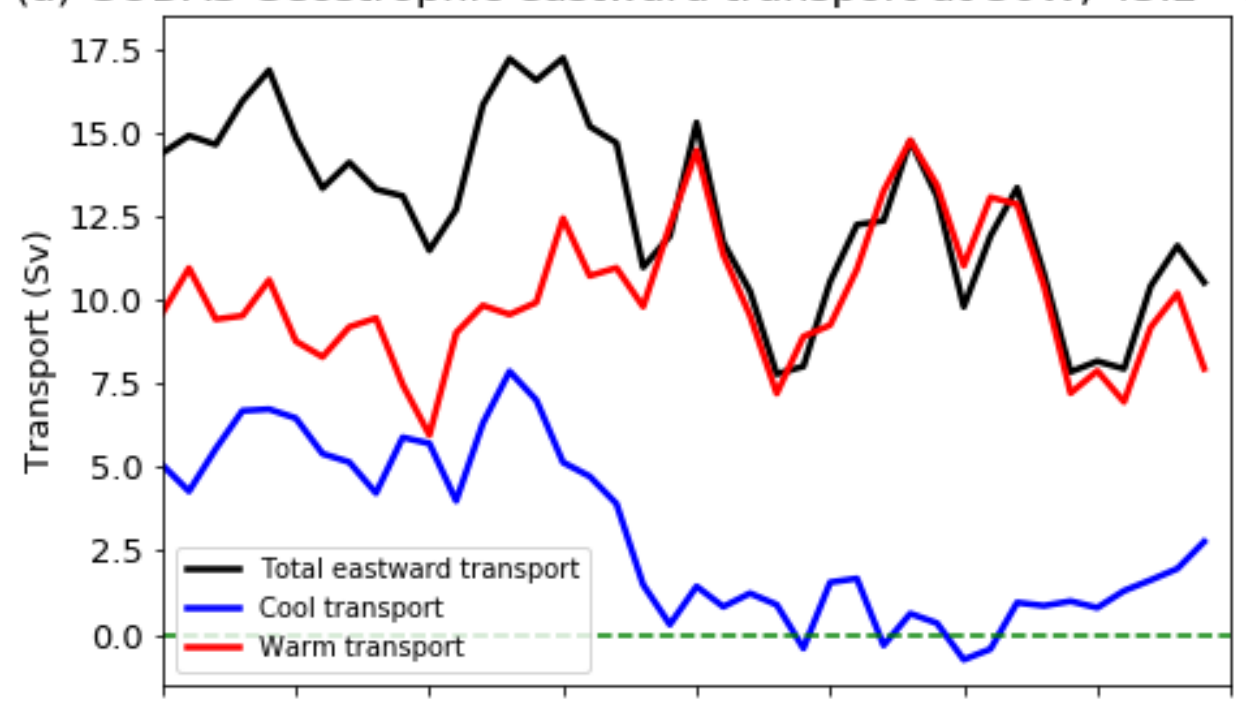

(b) EN4 Geostrophic eastward transport at 30W, $45.2-60.2 \mathrm{~N}$.

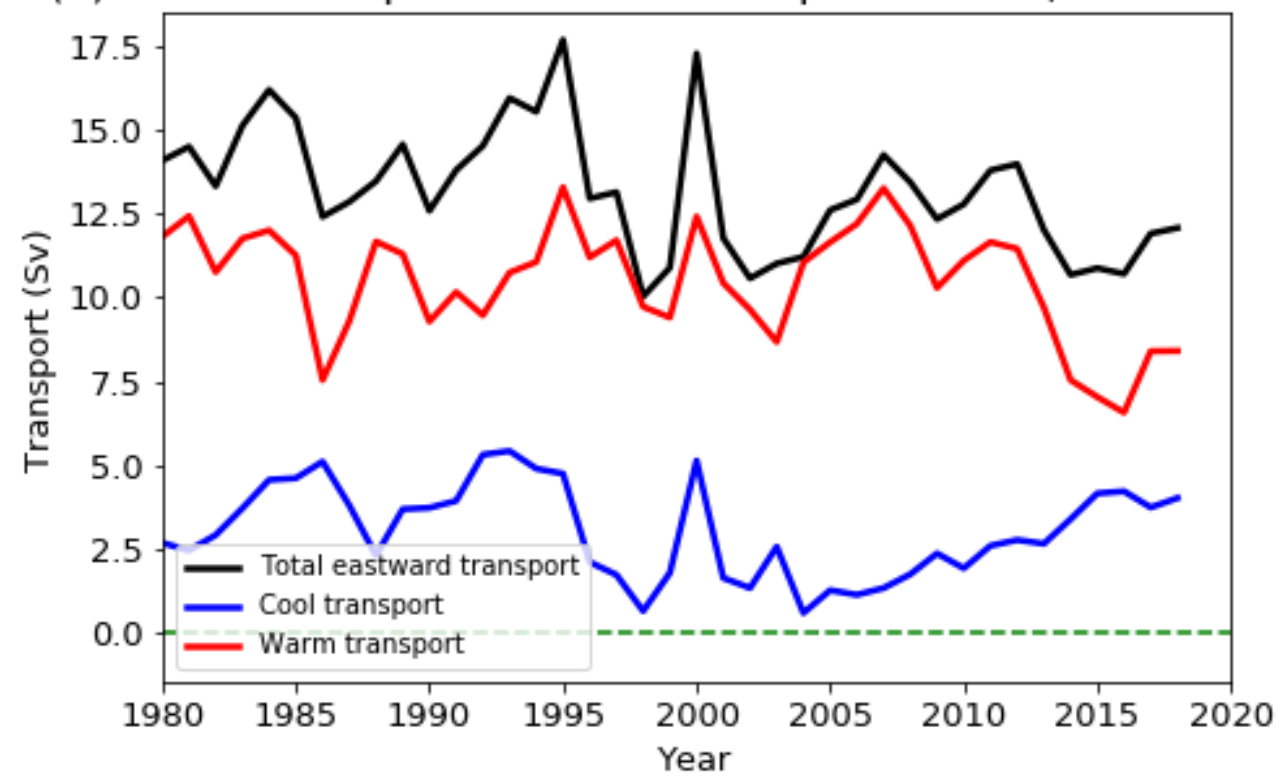

510 Figure 6: Geostrophic eastward transport time series (annual means) at $30{ }^{\circ} \mathrm{W}$ between $45.2{ }^{\circ} \mathrm{N}-60.2{ }^{\circ} \mathrm{N}$ and in the upper $1000 \mathrm{~m}$, for (a) GODAS and (b) EN4 datasets. "Cool" is defined here as temperatures $<11{ }^{\circ} \mathrm{C}$, "warm" is $\geq 11{ }^{\circ} \mathrm{C}$. 
(a) GODAS total eastward volume transport at 30W, $45.2-60.2 \mathrm{~N}$.

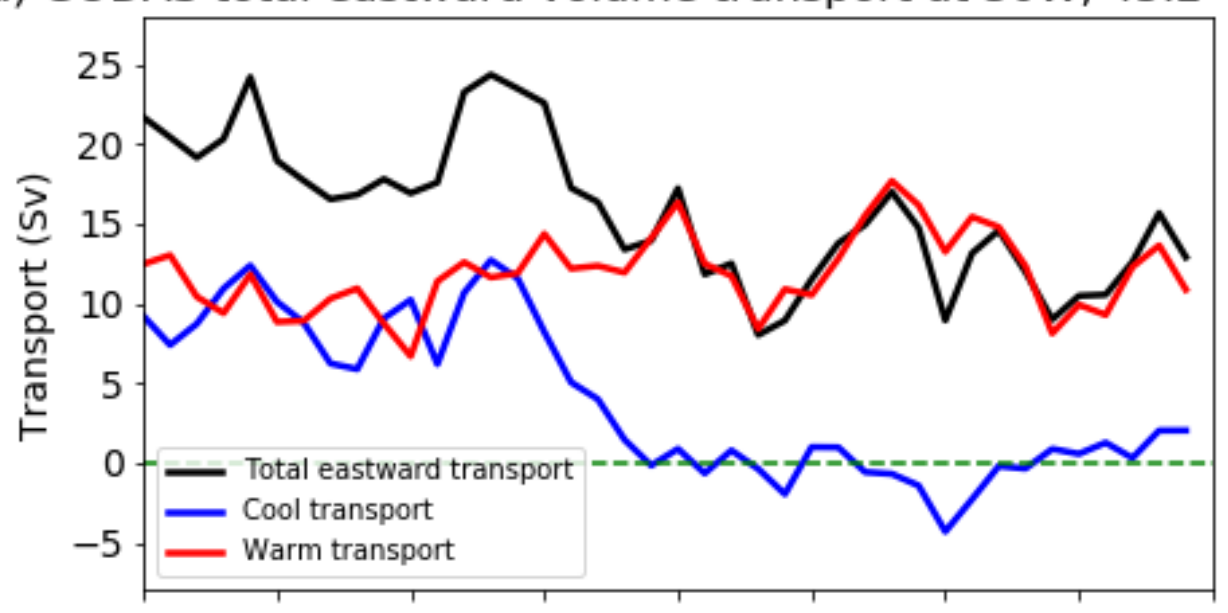

(b) ORCA12 total eastward volume transport at 30W, 45.2-60.2N.

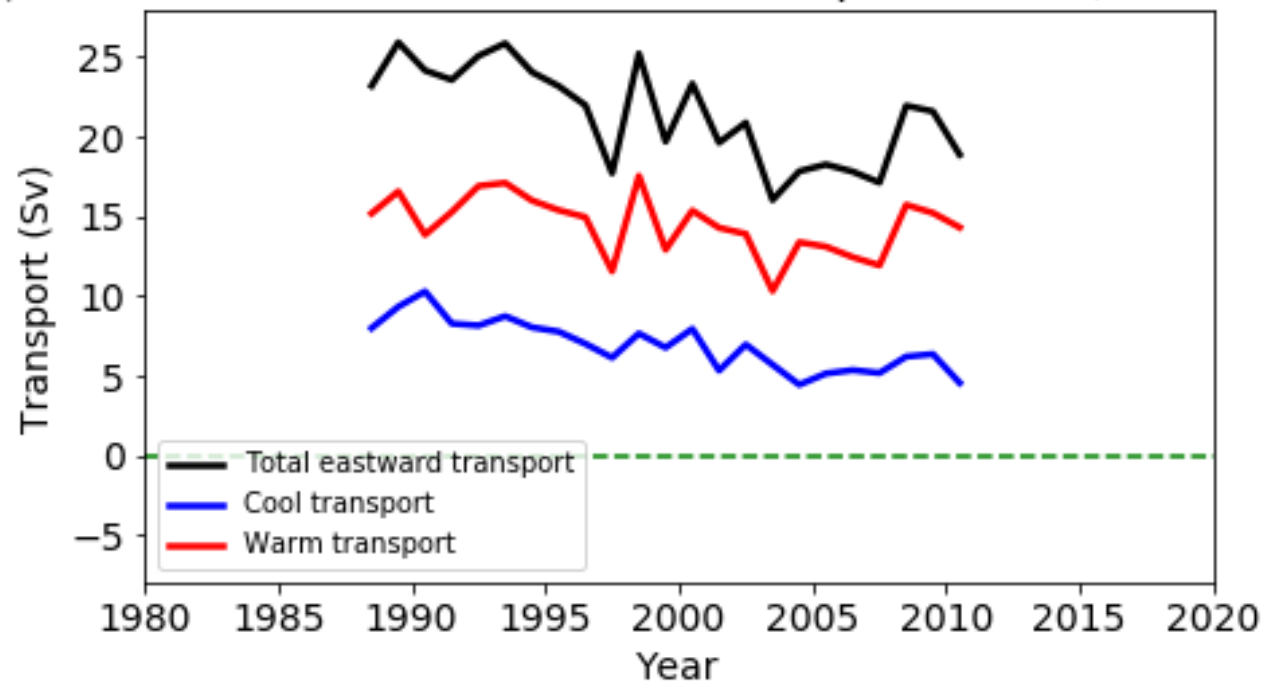

Figure 7: Total absolute eastward transport time series (annual means) at $30{ }^{\circ} \mathrm{W}$ between $45.2{ }^{\circ} \mathrm{N}-60.2{ }^{\circ} \mathrm{N}$ for (a) GODAS and (b) 
(a) Mean monthly transp.

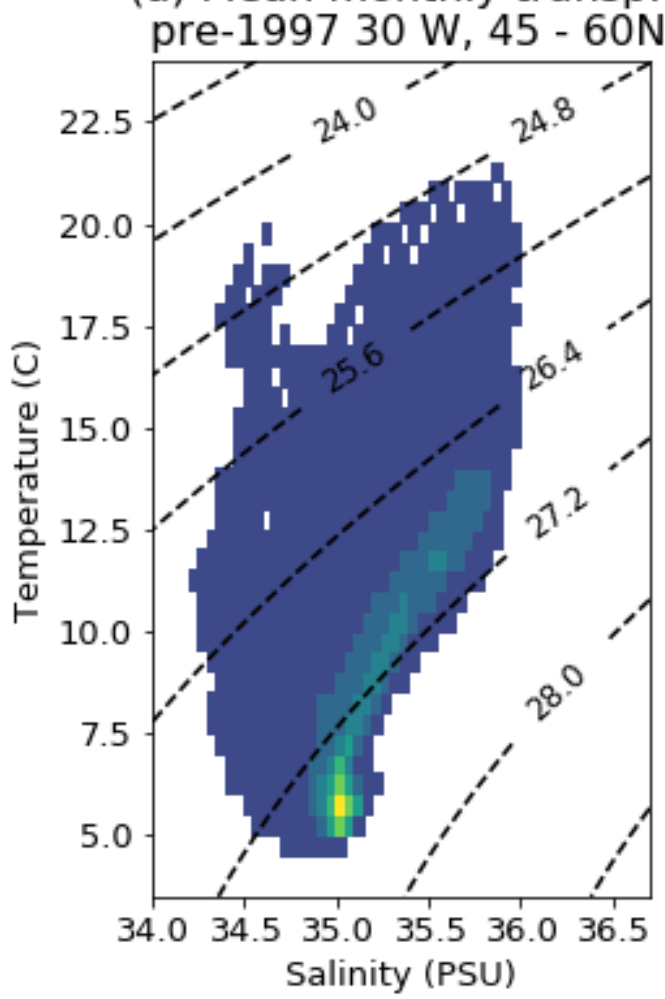

(b) Mean monthly transp.

\section{7 onwards 30 W, 45 - 60N}

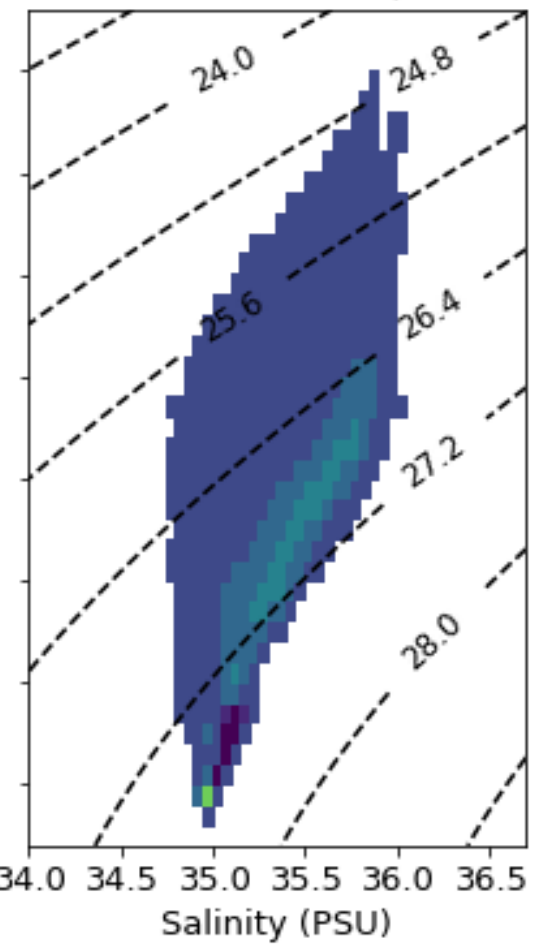

Figure 8: GODAS Temperature-Salinity binned eastward transport at $30^{\circ} \mathrm{W}$ between $40-58{ }^{\circ} \mathrm{N}$, in the upper $1000 \mathrm{~m}$ for (a) pre 1997 and (b) 1997 onwards. Dashed lines are isopycnals. The sum of the gridcells in (a) is $17.2 \mathrm{~Sv}$ and (b) $11.1 \mathrm{~Sv}$. 
(a) Mean monthly transp.

(b) Mean monthly transp.
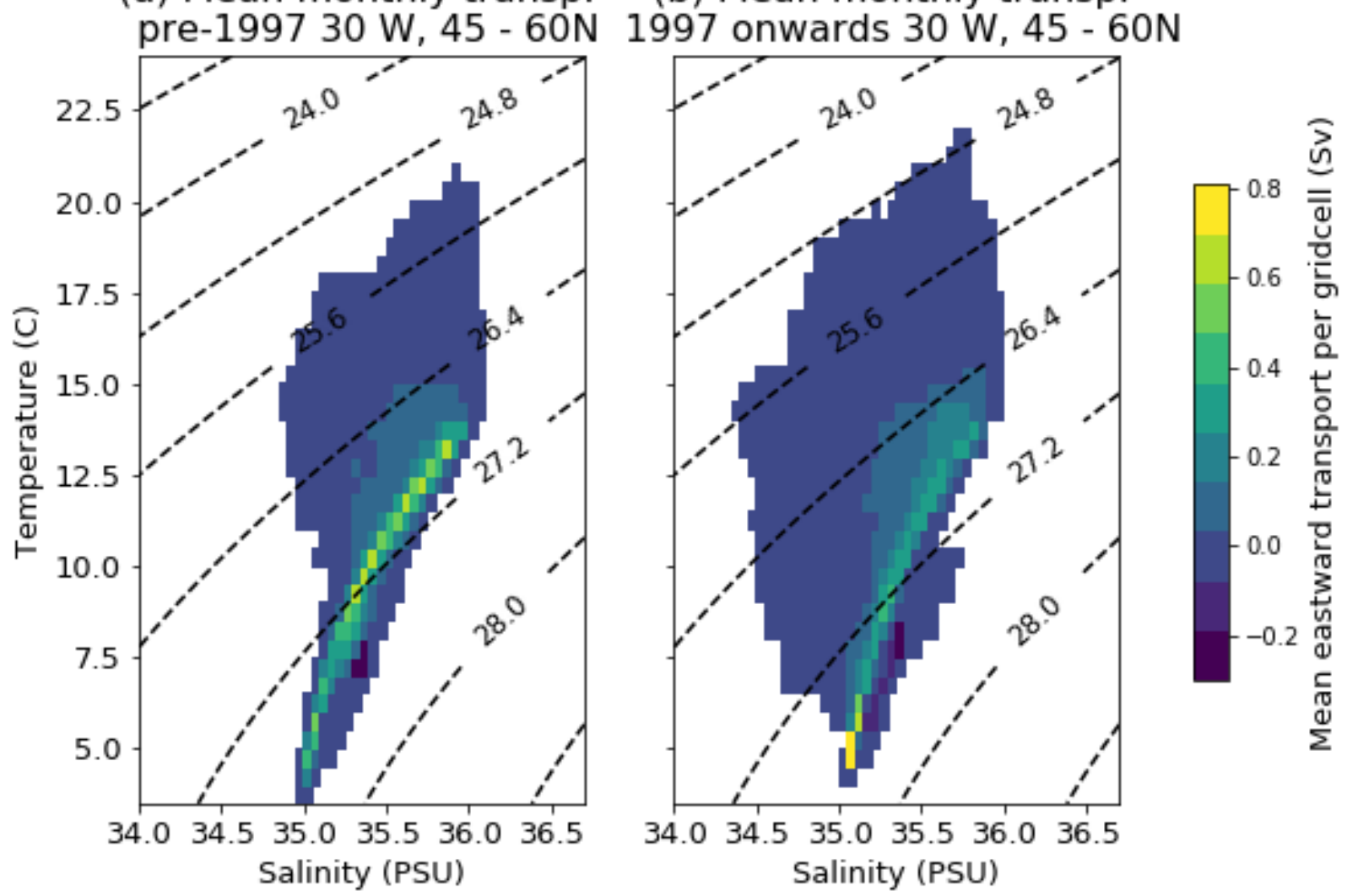

Figure 9: ORCA12 Temperature-Salinity binned eastward transport at $30^{\circ} \mathrm{W}$ between $40-58{ }^{\circ} \mathrm{N}$, in the upper $1000 \mathrm{~m}$ for (a) pre 1997 and (b) 1997 onwards. Dashed lines are isopycnals. The sum of the gridcells in (a) is $26.2 \mathrm{~Sv}$ and (b) $22.2 \mathrm{~Sv}$ 
https://doi.org/10.5194/os-2021-60

Preprint. Discussion started: 13 July 2021

(c) Author(s) 2021. CC BY 4.0 License.

(a) $\mathrm{V}$ transport, $58.1 \mathrm{~N}, 9.7-8.5 \mathrm{~W}$

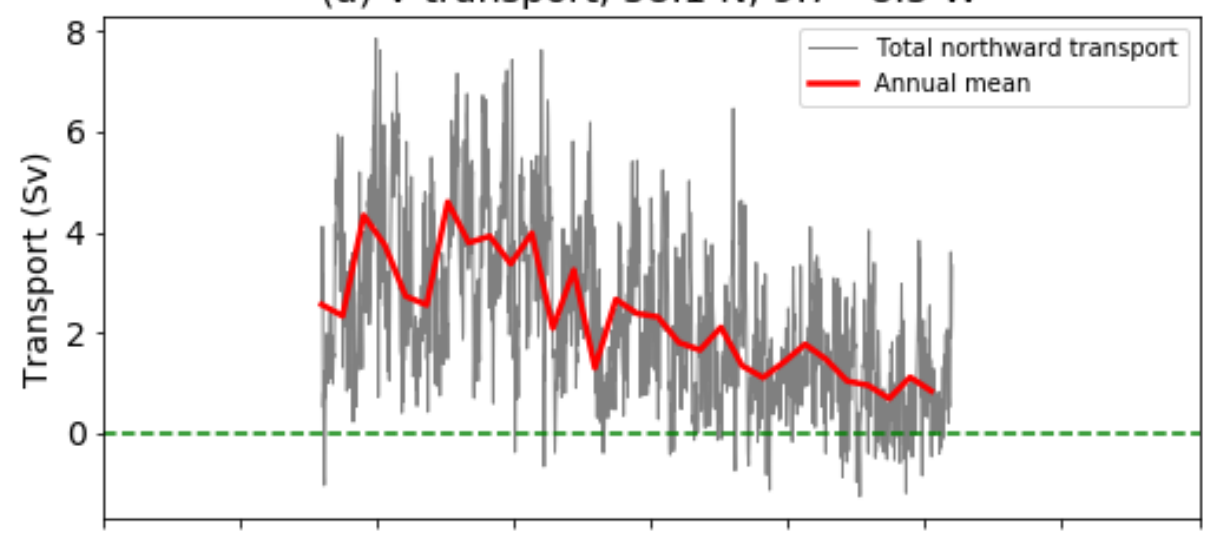

(b) V transport, $51.1 \mathrm{~N}, 11.5-10.6 \mathrm{~W}$

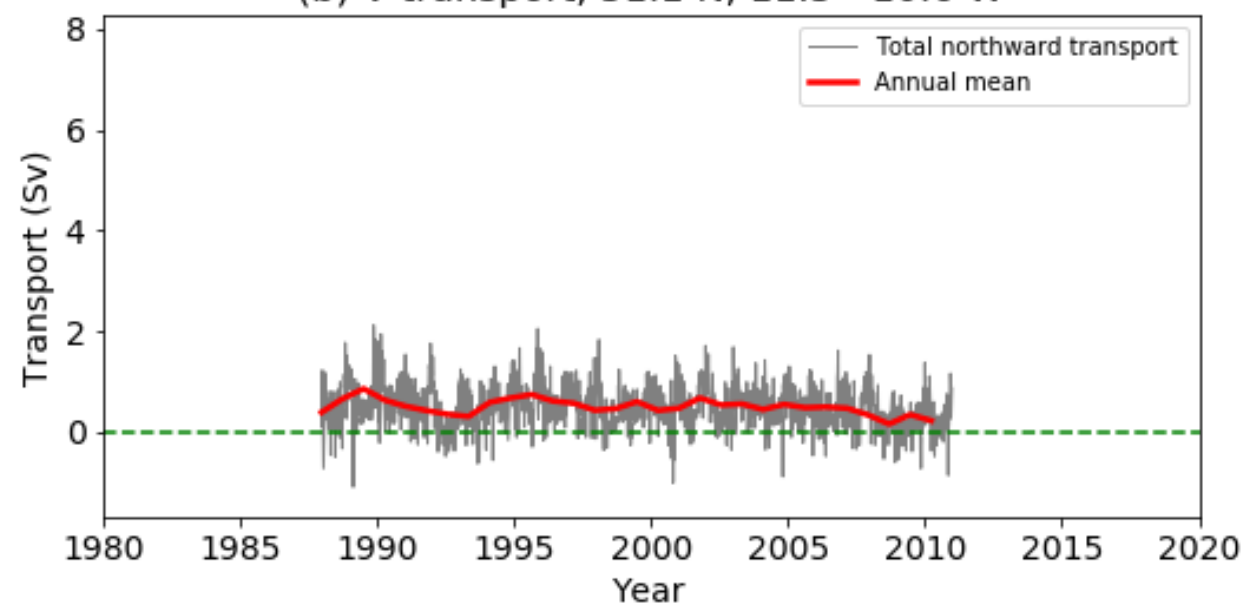

Figure 10: Northward total transport in the slope current (at the shelf edge) from the $\mathrm{ORCA12}^{\text {model at }(\mathrm{a}) \mathbf{5 8 . 1}}{ }^{\circ} \mathrm{N}, 9.74-8.5{ }^{\circ} \mathrm{W}$ and (b) $51.1{ }^{\circ} \mathrm{N}, 11.5-10.6{ }^{\circ} \mathrm{W}$. Black line shows the monthly mean, the red line shows the annual mean. Y-axis scales on (a) and (b) are different. 
https://doi.org/10.5194/os-2021-60

Preprint. Discussion started: 13 July 2021

(c) Author(s) 2021. CC BY 4.0 License. (a) $\log _{10}$ (fraction)

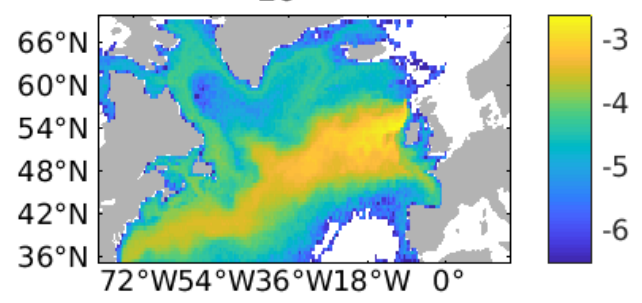

(c) mean depth (m)

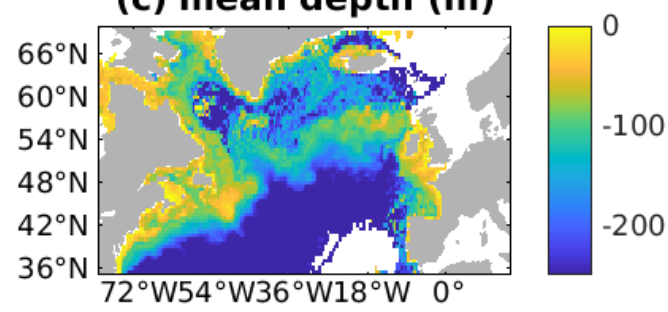

(b) mean age (days)

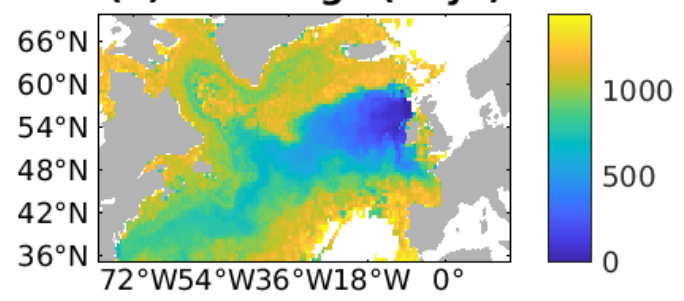

(d) mean potential temperature $\left({ }^{\circ} \mathrm{C}\right)$

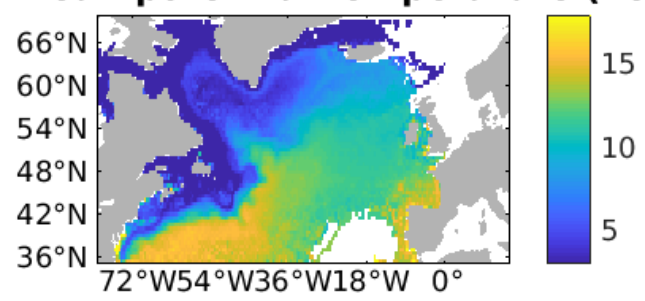

Figure 11: Ensemble mean particle statistics for the 1992-88 Ariane hindcast: (a) $\log _{10}$ fraction of total particles; (b) mean age in days; (c) mean depth in metres; (d) mean potential temperature in ${ }^{\circ} \mathrm{C}$ 


\section{(a) $\log _{10}$ (fraction)}

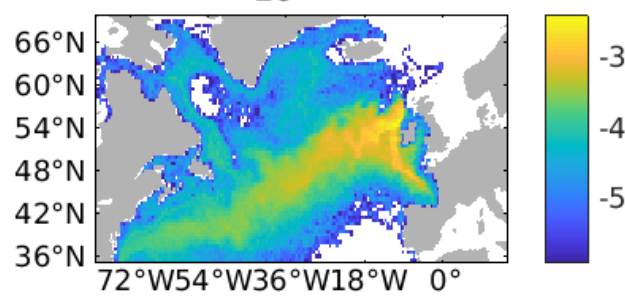

\section{(c) mean depth (m)}

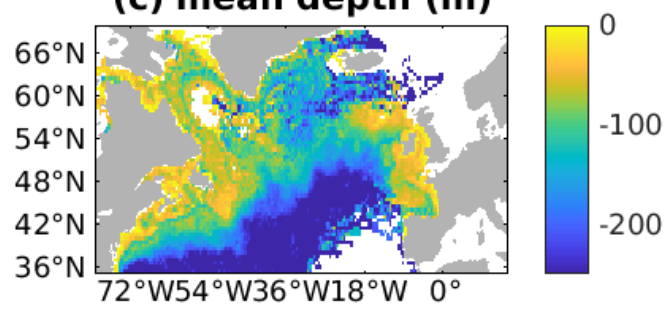

(b) mean age (days)

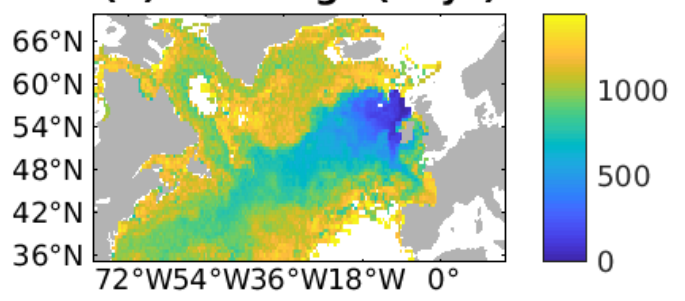

(d) mean potential temperature $\left({ }^{\circ} \mathrm{C}\right)$

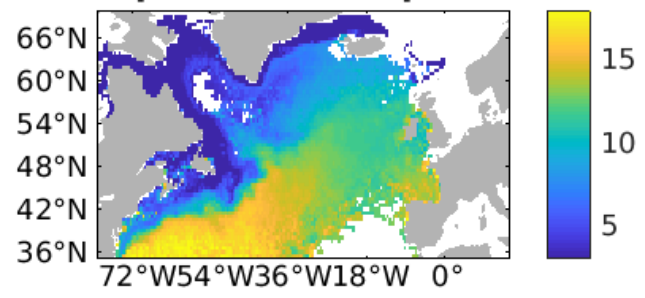

535 Figure 12: Ensemble mean particle statistics for the 2010-06 Ariane hindcast: (a) $\log _{10}$ fraction of total particles; (b) mean age in days; (c) mean depth in metres; (d) mean potential temperature in ${ }^{\circ} \mathrm{C}$ 
(a) $\log _{10}$ (fraction)

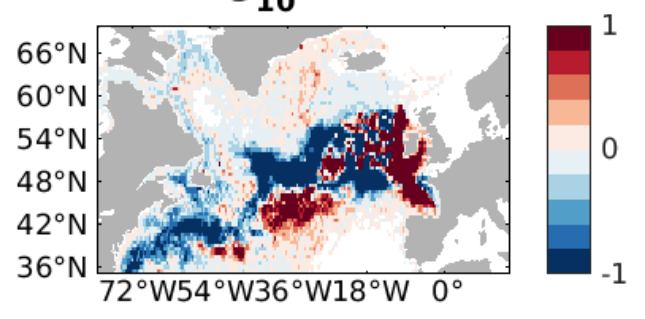

\section{(c) mean depth (m)}

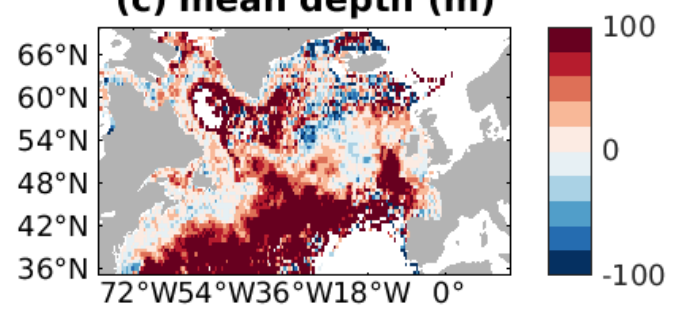

(b) mean age (days)

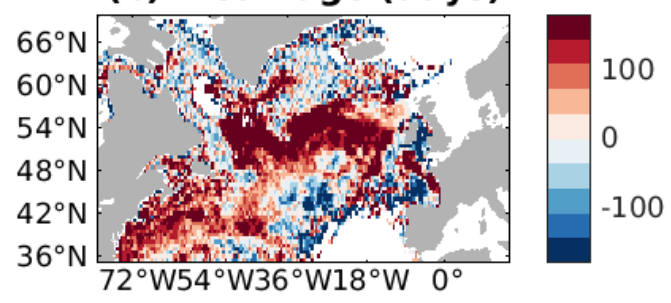

(d) mean potential temperature $\left({ }^{\circ} \mathrm{C}\right)$

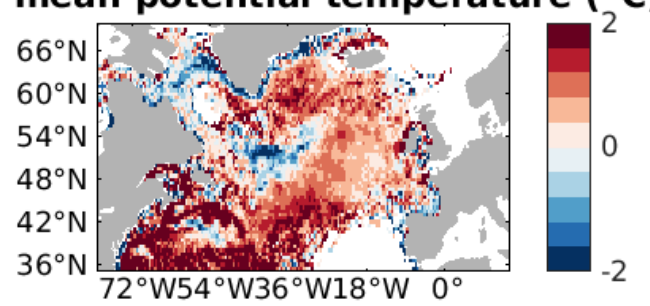

Figure 13: Difference between the ensemble mean statistical analyses of the ARIANE 4-year hindcasts: (a) 2010 mean - 1992 mean $\log _{10}$ fraction of total particles; (b) 2010 mean -1992 mean age in days; (c) 2010 mean -1992 mean depth in metres, positive = shallower; (d) 2010 mean - 1992 mean potential temperature in ${ }^{\circ} \mathrm{C}$. 
https://doi.org/10.5194/os-2021-60

Preprint. Discussion started: 13 July 2021

(c) Author(s) 2021. CC BY 4.0 License.
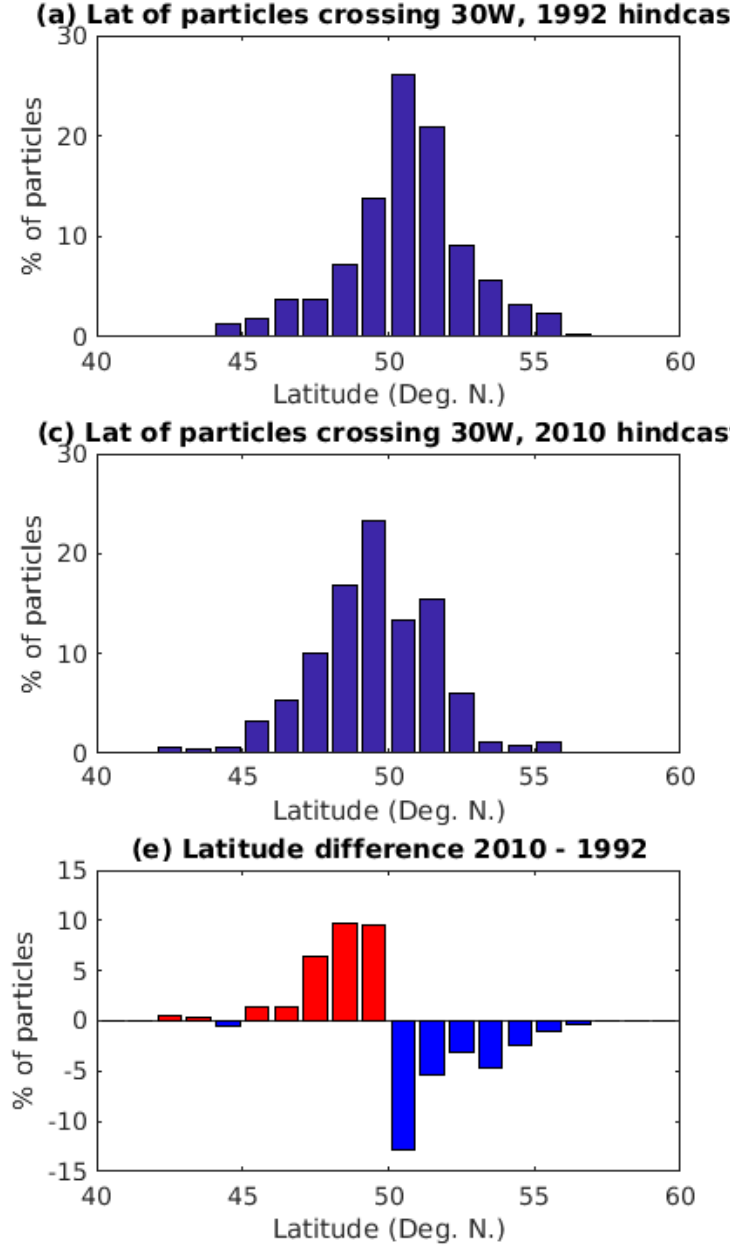

(b) Age of particles crossing 30W, 1992 hindcast

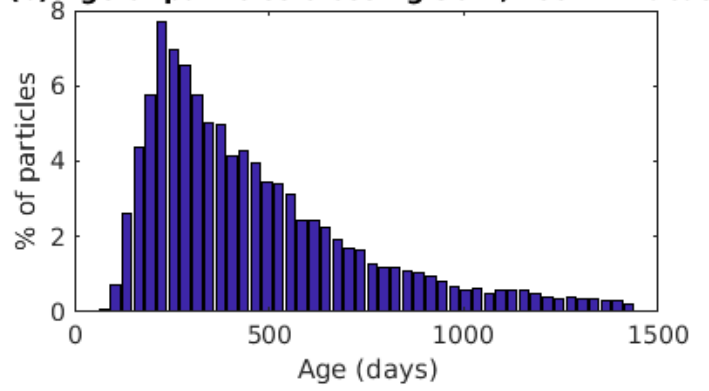

(d) Age of particles crossing 30W, 2010 hindcast

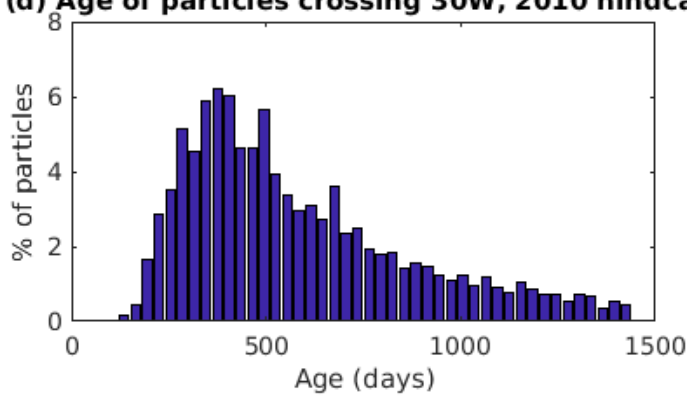

(f) Age difference 2010 - 1992

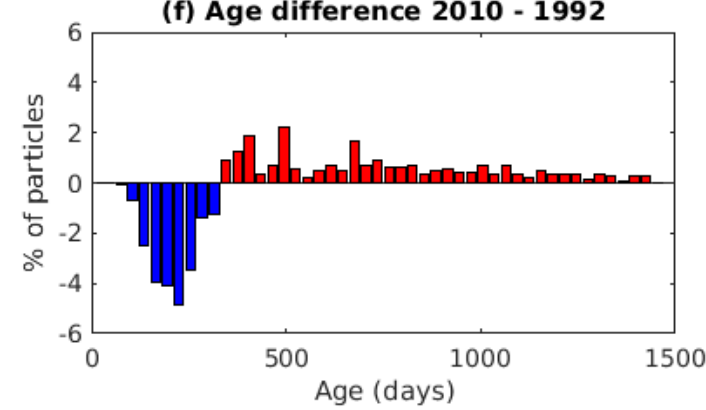

Figure 14: Histograms from the 1992 and 2010 hindcast, showing the latitude and age of unique particles crossing $30{ }^{\circ} \mathrm{W}$ for the first time (any further crossings are ignored). (a) 1992 particle latitude; (b) 1992 particle age; (c) 2010 particle latitude; (d) 2010 particle age; (e) latitude difference; (f) age difference. Positive difference = more particles in 2010 . Data binned by $1^{\circ}$ latitude and 30 days. 


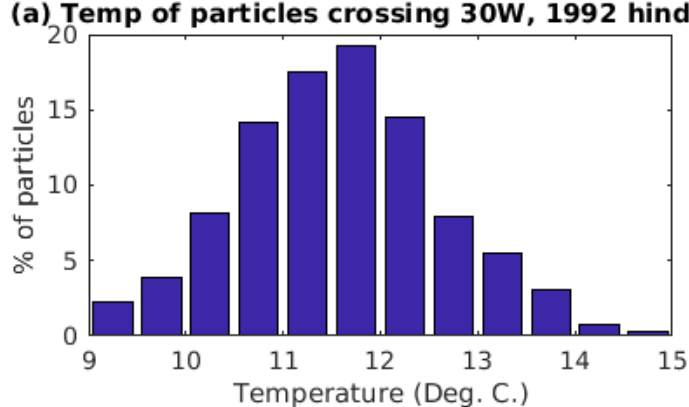

(c) Temp of particles crossing 30W, 2010 hindcast

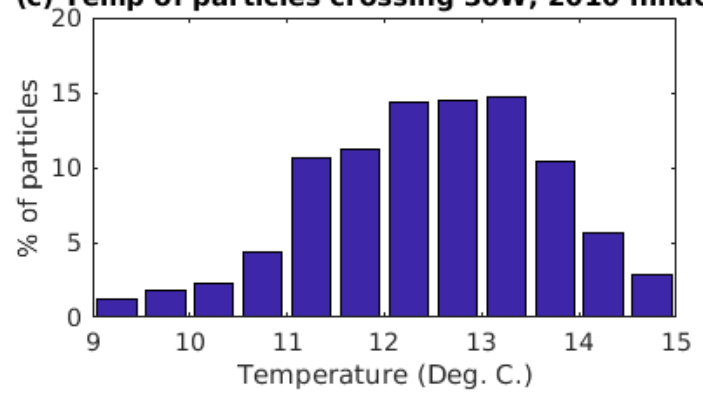

(e) Temperature difference 2010 - 1992

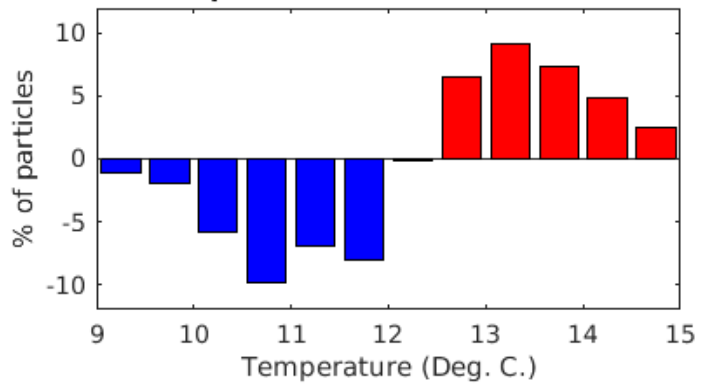

(b) Depth of particles crossing 30W, 1992 hindcast

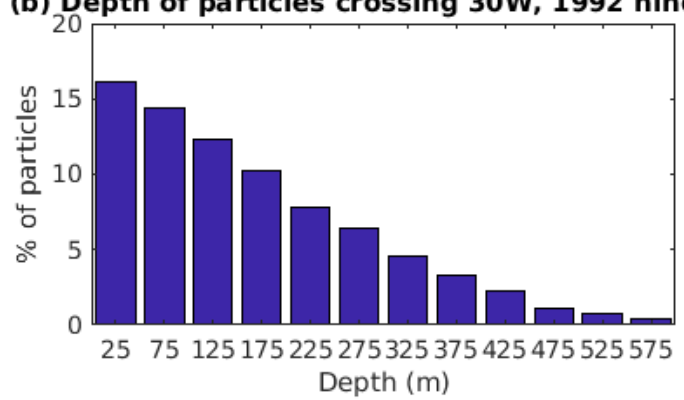

(d) Depth of particles crossing 30W, 2010 hindcast

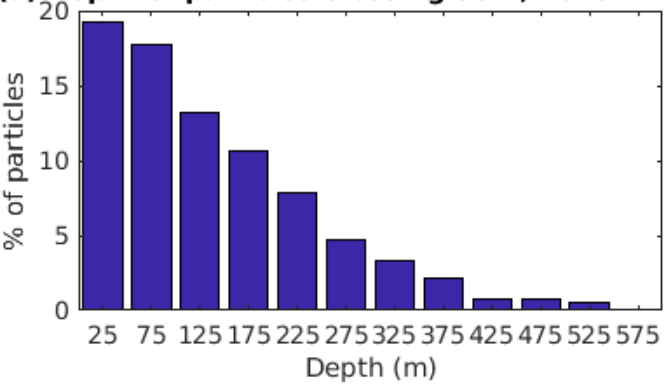

(f) Depth difference 2010 - 1992

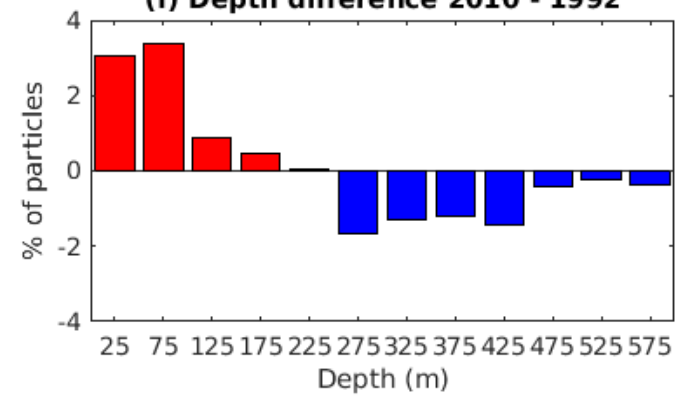

Figure 15: Histograms from the 1992 and 2010 hindcast, showing the temperature and depth of unique particles crossing $30{ }^{\circ} \mathrm{W}$

for the first time (any further crossings are ignored). (a) 1992 particle temperature; (b) 1992 particle depth; (c) 2010 particle temperature; (d) 2010 particle depth; (e) temperature difference; (f) depth difference. Positive difference = more particles in 2010. Data binned by $0.5{ }^{\circ} \mathrm{C}$ temperature and $50 \mathrm{~m}$ depth. 
https://doi.org/10.5194/os-2021-60

Preprint. Discussion started: 13 July 2021

(c) Author(s) 2021. CC BY 4.0 License.

555 Table 1: simple statistics to assess the spread of and difference between the two Ariane hindcasts

\begin{tabular}{|c|c|c|c|}
\hline Statistic & 1992 hindcast & 2010 hindcast & Difference 2010 - 1992 \\
\hline Latitude: Mean of crossing $30^{\circ} \mathrm{W}$ & $51.68^{\circ} \mathrm{N}$ & $50.73^{\circ} \mathrm{N}$ & $-0.95^{\circ} \mathrm{N}$ \\
\hline Latitude: Median of crossing $30^{\circ} \mathrm{W}$ & $51.72^{\circ} \mathrm{N}$ & $50.44^{\circ} \mathrm{N}$ & $-1.28^{\circ} \mathrm{N}$ \\
\hline Latitude: Standard deviation of crossing $30^{\circ} \mathrm{W}$ & $2.34^{\circ}$ & $2.66^{\circ}$ & $0.32^{\circ}$ \\
\hline Age: Mean of crossing $30^{\circ} \mathrm{W}$ & 498 days & 616 days & 118 days \\
\hline Age: Median of crossing $30^{\circ} \mathrm{W}$ & 420 days & 535 days & 115 days \\
\hline Age: Standard deviation of crossing $30^{\circ} \mathrm{W}$ & 278 days & 289 days & 11 days \\
\hline Depth: Mean of crossing $30^{\circ} \mathrm{W}$ & $177.8 \mathrm{~m}$ & $156.9 \mathrm{~m}$ & $-21 \mathrm{~m}$ \\
\hline Depth: Median of crossing $30^{\circ} \mathrm{W}$ & $147.6 \mathrm{~m}$ & $133.1 \mathrm{~m}$ & $-14.5 \mathrm{~m}$ \\
\hline Depth: Standard deviation of crossing $30^{\circ} \mathrm{W}$ & $138.7 \mathrm{~m}$ & $116.9 \mathrm{~m}$ & $-21.8 \mathrm{~m}$ \\
\hline Temperature: Mean of crossing $30^{\circ} \mathrm{W}$ & $12.0^{\circ} \mathrm{C}$ & $12.9^{\circ} \mathrm{C}$ & $0.9^{\circ} \mathrm{C}$ \\
\hline Temperature: Median of crossing $30^{\circ} \mathrm{W}$ & $12.0^{\circ} \mathrm{C}$ & $13.1^{\circ} \mathrm{C}$ & $1.1^{\circ} \mathrm{C}$ \\
\hline Temperature: Standard deviation of crossing $30^{\circ} \mathrm{W}$ & $1.2^{\circ} \mathrm{C}$ & $1.6^{\circ} \mathrm{C}$ & $0.4^{\circ} \mathrm{C}$ \\
\hline
\end{tabular}

